\title{
AVALIAÇÃO DO DESEMPENHO DE UM NOVO INSTRUMENTO O HIDRO SAVER PARA A DETERMINAÇÃO DA LÂMINA DE IRRIGAÇÃO
}

\section{FERNANDO ANTONIO FRANCO DA ENCARNAÇÃO}

Engenheiro Florestal

Orientador: Prof. Dr. NILSON AUGUSTO VILLA NOVA

Tese apresentada à Escola Superior de Agricultura "Luiz de Queiroz", da Universidade de São Paulo, para obtenção do título de Doutor em Agronomia Área de Concentração: Solos e Nutrição de Plantas.

\section{PIRACICABA}

Estedo de São Paulo - Brasil

FEVEREIRO - 1996 
Dados Internacionais de Catalogaçao na Publicação (CIP)

DIVISĀo DE BIBLIOTECA E DOCUMENTAÇĀO - Campus "Luiz de Quelroz"IUSP

\section{Encarnaçăo, Fernando Antonio Franco da}

Avaliaçăo do desempenho de um novo instrumento o "Hidro Saver" para a determinaçấo da lamina de Irrigaçăo / Fernando Antonio Franco da Encarnaçato. - - Piracicaba, 1996.

ธ3p.

Tese (doutorado) - - Escola Superior de Agricultura Luiz de Queiroz, 1996. Bibliografia.

1. Água do solo - Armazenamento 2. Equipamento agricola 3. Irrigaçâo - Lámina - Determinaçăo 1. Título 


\section{AVALIAÇÃO DO DESEMPENHO DE UM NOVO INSTRUMENTO O HIDRO SAVER PARA A DETERMINAÇÃO DA LÂMINA DE IRRIGAÇÃO}

FERNANDO ANTONIO FRANCO DA ENCARNAÇÃO

Aprovada em: 17.04 .96

Comissão julgadora:

Prof. Dr. Nilson Augusto Villa Nova

ESALQ/USP

Prof. Dr. Klaus Reichardt

ESALQ/USP

Prof. Dr. Miguel Ângelo Manieiro

CCA/USFSCAR

Prof. Dr. Pablo Vidal Torrado

ESALQ/USP

Prof. Dr. Dirceu Brasil Vieira

FEC/UNICAMP

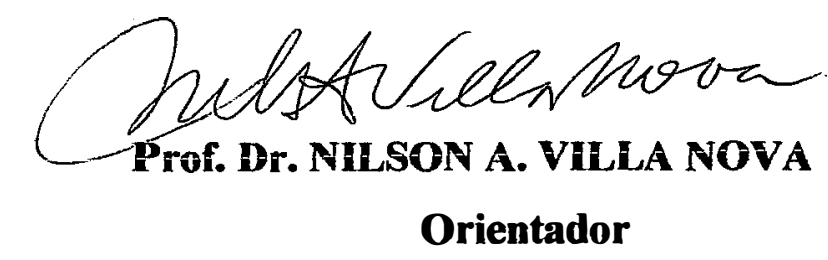


Ao Prof. Cláudio Madeira Melo pelo vasto conhecimento técnico, científico e cultural que acumulado ao longo de sua vida, e com o qual tenho o privilégio de poder contar para a execução e sucesso dos muitos trabalhos que já fizemos e de muitos outros que faremos juntos.

\section{DEDICO}

Ao Prof. Dr. Nilson Augusto Villa Nova pela sua coragem de viabilizar, com o seu conhecimento técnico e científico, a introdução de novos conceitos, conhecimentos e tecnologias inovadoras a ciência. 


\section{AGRADECIMENTOS}

A Deus por tudo. Obrigado Senhor.

À Universidade Federal de Alagoas - UFAL, e especialmente ao chefe do Departamento de Geologia e Topografia - GET, na pessoa do Prof. Paulo Roberto Coelho Araújo pelo apoio, paciência e compreensão que dedicou e dedica a minha pessoa, sem a qual as dificuldades do percurso não teriam sido vencidas.

Ao Prof. Perilo Rostan pelo empenho para a minha liberação para este curso.

Ao Prof. Nilson Augusto Villa Nova pelo incentivo, apoio, orientação e paciência que me dedicou para realização deste trabalho.

Ao Prof. Dr. Klaus Reichardt pelas lições de vida e conhecimentos científicos que pacientemente conseguiu passar-me.

Ao Prof. Dr. José Carlos de Souza Reis pelo apoio, incentivo e compreensão que me dedica ao longo de muitos anos de nossa amizade.

Ao Prof. Dr. Carlos Ramirez Franco da Encarnação pela força, incentivo e apoio.

Ao Prof. Cláudio Madeira Melo pela dedicação, empenho, competência e companheirismo com que participou de todas as etapas que antecederam à conclusão deste trabalho, e em muitos outros que virão. 
À Universidade Federal Rural de Pernambuco, especialmente ao Departamento de Física do Solo na pessoa do Prof. Dr. José Júlio Vilar Rodrigues, por permitir a execução dos trabalhos no laboratório da mesma.

Ao Prof. José Fernando Wanderlei Fernandes Lima e sua equipe pelo apoio na execução dos trabalhos no campo e nos laboratórios da Estação Experimental do Carpina. Agradeço, também, ao pessoal do laboratório: Edmilson, Júlio, Djalma e Josafá.

À Escola Superior de Agricultura "Luiz de Queiroz", em especial ao Depto. de Solos, Geologia e Fertilizantes, e ao Depto. de Física e Meteorologia, pela viabilização deste trabalho.

Aos meus filhos Fernando Júnior e Carlos Eduardo pelo esforço e apoio que dedicaram na execução deste trabalho e em muitos outros.

À Dra. Vilma Maria Silva pelo companheirismo na execução deste e de muitos outros trabalhos. 


\section{SUMÁRIO}

\section{Página}

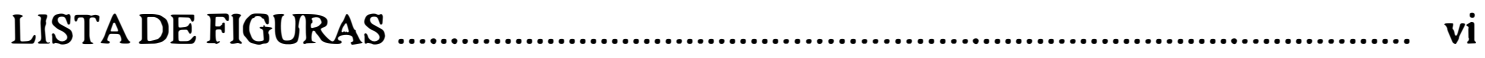

LISTA DE TABELAS ............................................................................. vii

LISTA DE ABREVIATURAS E SÍMBOLOS.................................................. viii

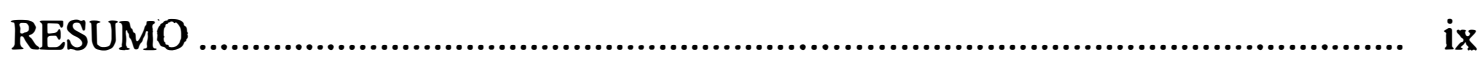

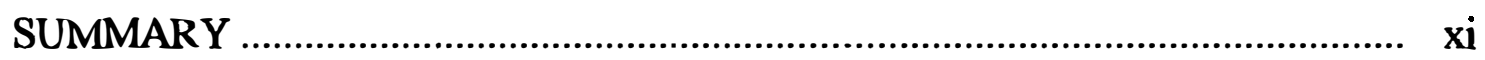

1. INTRODUÇÃO ................................................................................... 1

2. REVISÃO DE LITERATURA ............................................................... 4

2. 1. Conceitos teóricos .................................................................................. 4

2. 2. Métodos de medida da umidade do solo ................................................. 8

2. 2. 1. Gravimetria ................................................................................ 8

2. 2. 2. Membrana de pressão................................................................ 9

2. 2. 3. Funil de placa porosa.............................................................. 10

2. 2. 4. Tensiômetro.......................................................................... 10

2. 2. 5. Moderação de nêutrons........................................................ 12

1. MATERIAL E MËTODOS ….................................................................... 14

3. 1. Área experimental e clima …........................................................... 14

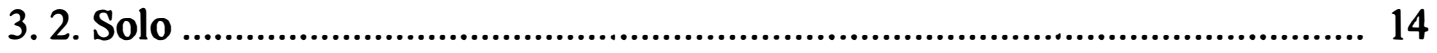

3. 3. Parcelas experimentais e medições de campo .......................................... 15

3. 3. 1. Instrumentos de medição ........................................................... 15

3. 3. 1. 1. Potencial da água no solo ............................................ 15

3. 3. 1. 2. O HIDRO SAVER .......................................................... 18

3. 3. 1. 2. 1. Descrição do instrumento..................................... 19

3. 3. 1. 2. 2. Arquitetura e dimensões..................................... 19

3. 3. 1. 2. 3. Base teórica de funcionamento............................ 22

3. 3. 1. 2. 4. Montagem e funcionamento ................................. 25

3. 3. 2. Experimento de campo ................................................................ 28

3. 3. 2. 1. Medidas da umidade do solo pelo método Gravimétrico e pelo 
HIDRO SAVER

3. 4. Testes dos métodos gravimétrico e do HIDRO SAVER para vários tipos

de amostras 32

3. 4. 1. Testes com corpos de provas 32

3. 4. 1. 1. Características dos corpos de prova e procedimento 32

3. 4. 2. Testes com amostras de labaratório 32

3. 4. 2. 1. Características das amostras e procedimento 32

3. 4. 3. Testes especiais com umidades aleatória 33

3. 4. 3. 1. Características das amostras e procedimento. 33

3. 4. 4. Testes da capacidade máxima de armazenamento de água das amostras 34

3. 4. 4. 1. Características das amostras e procedimento 34

4. RESULTADO E DISCUSSÃO 36

4. 1. Desempenho do HIDRO SAVER 36

4. 1. 1. Condições operacionais 36

4. 1. 2. Resultados relativos aos corpos de prova 37

4. 1. 3. Resultados relativos aos testes de laboratório 39

4. 1. 3. 1. Com amostras desestruturadas submetidas à panela de pressão. 39

4. 1. 3. 2. Teste com umidades aleatórias em amostras com estrutura indeformada 43

4. 1. 3. 3. Testes da capacidade máxima de retenção de água em amostras indeformadas 45

4. 1. 4 Resultados relativos aos experimentos de campo 47

5. CONCLUSÕES 52

6. REFERÊNCIAS BIBLIOGRÁFICAS 53 APÊNDICE 59 


\section{LISTA DE FIGURAS}

Página

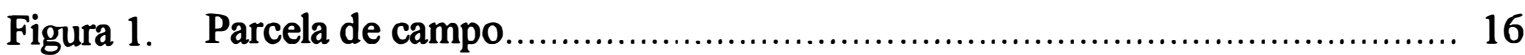

Figura 2. Tensiômetro de manômetro com escala em centibar............................ 17

Figura 3. Visão lateral em corte do HIDRO SAVER ....................................... 20

Figura 4. Distribuição dos componentes sobre a base do HIDRO SAVER............ 21

Figura 5. O HIDRO SAVER pronto para o uso.......................................... 23

Figura 6. Esquema dos planos de amostragens nas parcelas de campo................. 30

Figura 7. Resultados dos testes com corpos de provas, média por elemento .......... 39

Figura 8. Variação dos valores de umidade a 0,3 atm calculados pelo método da câmara de pressão e pelo HIDRO SAVER ............................................ 40

Figura 9. Variação dos valores de umidade a 15,0 atm calculados pelo método da câmara de pressão e pelo HIDRO SAVER

Figura 10. Variação dos dados de umidade aleatória em amostra com estrutura indeformada, média de três repetições.

Figura 11. Testes da capacidade máxima de retenção de água das amostras, média de três repetições.

Figura 12. Experimento de campo variação de umidade em função da profundidade, perfil I, médias de três repetições.

Figura 13. Experimento de campo variação de umidade em função da profundidade, perfil II, médias de três repetições 


\section{LISTA DE TABELAS}

Página

Tabela 1. Resultados dos testes de laboratório, determinação da capacidade máxima de retenção de água pelo método gravimétrico (LG) e pelo HIDRO SAVER (LHS) utilizando corpos de prova 38

Tabela 2. Resultados dos testes de laboratório com amostras desestruturadas. Comparação das lâminas de água calculadas pelo método da câmara de pressão com os valores determinaods pelo HIDRO SAVER

Tabela 3. Resultados dos testes de laboratório, medidas da capacidade máxima de armazenamento de água das amostras secas em estufa a $105^{\circ} \mathrm{C}$ determinadas pelo HIDRO SAVER.

Tabela 4. Teste de laboratório com umidades aleatória, comparação das lâminas de água calculadas pelo método gravimétrico (LG) e com as lâminas de água determinadas pelo HIDRO SAVER (LHS), utilizando amostras indeformadas do perfil I

Tabela 5. Teste de laboratório na capacidade máxima de armazenamento de água das amostras, comparação das lâminas de água, calculadas pelo método gravimétrico (LG) com as lâminas de água determinadas pelo HIDRO SAVER (LHS), utilizando amostras indeformadas do perfil II

Tabela 6. Primeiro experimento de campo, comparação das lâminas de água calculadas pelo método gravimétrico (LG) com as lâminas de água determinadas pelo HIDRO SAVER (LHS). Dados obtidos em amostras indeformadas no PODZÓLICO AMARELO perfil I 49

Tabela 7. Segundo experimento de campo, comparação das lâminas de água calculadas pelo método gravimétrico (LG) com as lâminas de água determinadas pelo HIDRO SAVER (LHS). Dados obtidos em amostras indeformadas no PODZÓLICO AMARELO do perfil II 


\section{LISTA DE ABREVIATURAS E SÍMBOLOS}

CA - Capacidade de armazenamento de água.

LC - Lâmina d'água complementar (volume de água necessário para levar o solo de um nível qualquer de umidade $\theta$, até o limite máximo de armazenamento de água $\theta \mathrm{m}$, sem atingir a umidade de saturação $\theta$ s).

HSU - Lâmina d'água determinada a partir da amostra úmida.

HSS - Corresponde à capacidade máxima de armazenamento de água da amostra determinada pelo HIDRO SAVER.

LHS - Lâmina d'água equivalente calculada pela fórmula:

LHS = HSS - HSU

onde,

HSS - Lâmina d'água a partir da amostra seca em estufa a $105^{\circ} \mathrm{C}(\mathrm{mm})$

HSU - Lâmina d'água a partir da amostra úmida (mm)

LG - Lâmina d'água calculada gravimetricamente pela fórmula:

LG $=($ PSU - PSS $) /$ PSS . Da. h

onde,

PSU - Peso da amostra de solo úmida (g)

PSS - Peso da amostra de solo seco em estufa a $105^{\circ} \mathrm{C}$ (g)

Da - Densidade do solo (g/cm3)

h - Altura da amostra (cm) 


\title{
AVALLAÇÃO DO DESEMPENHO DE UM NOVO INSTRUMENTO, O "HIDRO SAVER", PARA A DETERMINAÇÃO DA LÂMINA DE IRRIGAÇÃO
}

\author{
Autor: Prof. FERNANDO ANTONIO FRANCO DA ENCARNAÇÃO
}

Orientador: Prof. Dr. NILSON A. VILLA NOVA

\section{RESUMO}

O HIDRO SAVER é um novo instrumento desenvolvido para determinar a lâmina d'água complementar - LC (quantidade de água necessária para levar o solo de um nível de umidade $\theta \mathbf{a}$ qualquer, até o limite máximo de armazenamento $\theta \mathrm{m}$, sem atingir a saturação $\theta$ s), a partir de qualquer nível de umidade no solo, e de modo rápido, simples e preciso, sem a necessidade de cálculos, interpretações ou ajustes matemáticos dos seus resultados.

Para testar a performance e a precisão do novo instrumento, um esquema experimental foi conduzido, envolvendo as determinações nele obtidas e comparando-as com as dos métodos gravimétrico e da panela de pressão, em laboratório e no campo. No laboratório, foram usadas amostras de solo, com estrutura indeformada para a determinação da sua densidade aparente, pelo método do torrão, e amostras de solo desestruturadas para determinações de umidade.

As amostras utilizadas neste estudo são as mesmas que estão sendo coletadas para um trabalho de classificação dos solos do estado de Pernambuco, conduzido pelo Departamento de Solos da Universidade Federal Rural de Pernambuco UFRPE. 
Determinou-se a capacidade de armazenamento de água das amostras pelos métodos clássicos de panela de pressão (a 0,3 e $15 \mathrm{~atm}$ ), por gravimetria e pelo HIDRO SAVER. Os dados obtidos por gravimetria foram transformados em lâmina de água equivalente para comparação com os dados obtidos pelo HIDRO SAVER.

No experimento de campo, o método clássico para determinação da capacidade de campo foi aplicado em dois perfis de solo situados na Estação Experimental do Carpina - PE (latitude $7^{0} 47^{\prime}$ Sul, longitude $35^{\circ} 15^{\prime} \mathrm{W}$. Gr. e altitude de $178 \mathrm{~m}$ ). As amostras coletadas neste experimento, com estrutura indeformada, foram também levadas ao HIDRO SAVER para comparação dos resultados obtidos pelos dois métodos.

No laboratório, as amostras de campo foram também utilizadas para mais uma comparação entre os resultados obtidos por gravimetria e pelo novo instrumento.

Em outros experimentos corpos de prova foram confeccionados com areia e cimento, em cilindros amostradores, de modo a comportarem-se como solo, no que se refere à absorção de água. Nestes, evitaram-se fontes de variações como as perdas, a expansão e a contração do material de forma a prestarem-se como tratamento controle para aferir os resultados obtidos por gravimetria e pelo HIDRO SAVER.

A análise estatística dos resultados pelo teste de Tukey em nível de $10 \%$, revelou não existir diferença significativa entre os dados obtidos pelo método gravimétrico e pelo novo instrumento. 


\title{
Author: Prof. FERNANDO ANTONIO FRANCO DA ENCARNAÇÃO
}

\author{
Adviser: Prof. Dr. NILSON A. VILLA NOVA
}

SUMMARY

The HIDRO SAVER is an equipment designed for private or laboratorial use to deternine the complementary irrigation water depth (water amount required to take the soil from an unspecified water content $\theta \mathbf{a}$ to its maximal water holding capacity $\theta \mathbf{m}$, not reaching the saturation point $\theta$ s.

The work is promptly performed in a simple and accurate way, and does not call for calculations or mathematical help.

To assess the performance as well as the accuracy of this new instrument an experimental scheme has been devised and conducted, comparing the gravimetric method and the pressure plate, both in the field and indoors. In the laboratory, soil samples with the structure of the field were used for determinations of bulk density by the clod method, and soil water content.

The soil samples were identical to the ones used by the Department of the State of Pernambuco Soil Analysis and Classification. The water holding capacity of the samples by the standard methods of the pressure plate (at 0.3 and $15 \mathrm{~atm}$ ), by gravimetric techniques and by the new instrument the HIDRO SAVER have been performed. Data collected from the experiments with the gravimetric technique have 
been converted to the equivalent water depth, to balance against the readings of the new instrument.

In the field the classical method to determine field capacity has been used for two soil profiles located at Estação Experimental de Carpina (PE) (latitude $7^{\circ} 47^{\prime \prime}$ South, longitude $35^{\circ} 47^{\prime \prime}$ West, at $178 \mathrm{~m}$ of altitude).

The samples collected for this experiment have also been used for the two former methods.

In the laboratory the field samples have also been used for more than one balance against the readings obtained from the gravimetric method and by the new instrument.

Tofurther test the new instrument, artificial probes were made with sand and cement, in cylindrical shape, to behave like soils and to serve as reference for water absorption capacity.

In these samples the losses, the expansion and shrinkage of the material were avoided, in order to better compare the readings taken by gravimetry and by the HIDRO SAVER. The test pieces were also dried in oven at $105^{\circ} \mathrm{C}$.

After this they were inserted in the HIDRO SAVER to determine water storage capacities. Next, the wetting indexes were calculated.

The values obtained were turmed into equivalent water depths to balance the results.

The statistical analysis of the results showed no significant differences among the data collected by the gravimetric method and by the new instrument - the HIDRO SAVER.

It must however be noted that the wetting values showed slight differences that could be a consequence of hysteresis, taking into account that the new instrument is based on wetting indexes and not drying as in the other techniques.

Therefore values of water storage capacity obtained by the other methods were always smaller. Two equations were used for correlation; one for the gravimetric method and the one for the HIDRO SAVER. The equations obtained do not differ between themselves and have correlation coefficients close to one. 


\section{INTRODUÇĀO}

O solo é o reservatório natural de água que embora possa reter, em termos relativos, uma grande quantidade de água, nem toda ela está prontamente disponivel para as plantas: Com efeito, a água é retida no solo pela ação de fenômenos físicos e/ou químicos, que caracterizam o denominado potencial da água no solo, através dos seus componentes, (potencial gravitacional, matricial, osmótico etc...) cuja soma algébrica define o seu potencial total. Tais componentes dependem de vários fatores, inclusive do próprio nível de umidade do solo, e apresentam intervalos de variação cuja amplitude pode ser de várias ordens de grandeza.

O armazenamento de água do solo está diretamente relacionado à distribuição dimensional dos seus poros. Os diâmetros destes, por sua vez, são condicionados pela textura e grau de estruturação das partículas sólidas. Além disso, a capacidade de armazenamento é ainda fortemente influenciada pela natureza das partículas sólidas do solo (minerais ou orgânicas).

O solo como sistema é trifásico. A interação sólido-líquido-gás, promove no interior do perfil o surgimento dos fenômenos de adsorsão, adesão e capilaridade, que se constituem nas forças que definem o grau e intensidade da dinâmica da água no solo, sob condição não saturada.

Sob condições naturais, ocorrem variações significativas no nível de umidade no solo, devido à chuva, à evaporação, à transpiração e à drenagem. Tais variações podem ocorrer em períodos bem curtos, afetando basicamente os horizontes mais superficiais. Estes horizontes são os de maior relevância agronômica, devido ao fato de conterem a chamada rizosfera da maioria das plantas cultivadas, e exigem, 
portanto, um conhecimento mais acurado, tanto da dinâmica da umidade quanto dos fatores que a controlam.

A capacidade de armazenamento de água no solo (CA) é obtida pela diferença entre a capacidade de campo (CC), que representa o limite superior de retenção de água pelo solo, e o ponto de murcha permanente (PMP), que representa o limite inferior da água disponível.

O PMP, assim como a CC, são parâmetros da umidade do solo, de grande interesse prático. $O$ primeiro é aceito e tem seu uso consagrado na física do solo, sendo pouco discutido, talvez porque, na prática, muito antes deste nível de umidade ser atingido a produção da cultura já estaria comprometida.

Por outro lado, a CC representa o limite superior da capacidade de armazenamento de água no solo, de modo que a quantidade de água que ultrapassar este limite representa um custo inútil sobre a produção, além de causar degradação ao solo pela lixiviação dos nutrientes através do perfil.

Como nem toda a água retida no solo está prontamente disponível para as plantas, apenas uma pequena parte da CA pode ser considerada prontamente disponível para elas, e essa parte é definida, então, como lâmina de água útil (LU) ou água disponível ( $\mathrm{AD}$ ). $\mathrm{O}$ maior volume de água retida pelo solo encontra-se na faixa de umidade mais próxima ao limite superior da capacidade de armazenamento. À medida que o solo perde umidade, a água nele remanescente vai se tornando cada vez mais fortemente retida e, conseqüentemente, menos disponível para as plantas.

A idéia de quantificar a capacidade de armazenamento de água do solo vem do início deste século, como já pesquisavam ALWAY e McDOLE (1917). Vários métodos foram desenvolvidos visando a sua medida ou estimativa.

Além do alto nível de complexidade que envolve a água no solo e sua dinâmica, fenômenos como a histerese podem, muitas vezes, alterar os resultados de um método de medida da umidade do solo.

Um método ou técnica de medida é tão mais preciso quanto menos passos ou etapas sejam necessárias para que se obtenha o resultado final, graças a uma menor probabilidade da propagação de erros, obviamente, considerando-se que, em 
todas as condições de contorno sejam tomados os devidos cuidados na execução da metodologia.

Vários métodos foram desenvolvidos para medir a umidade no solo, e esses métodos são baseados em características físicas, químicas ou nucleares que variam com a umidade. Para validar um determinado método de medida da umidade do solo toma-se como padrão, até os dias de hoje, o método gravimétrico, que se baseia unicamente na perda de massa de uma amostra quando aquecida em estufa a $105^{\circ} \mathrm{C}$, até atingir peso constante. Porém, este método nada diz sobre a dinâmica da água e do seu estado de energia no solo, em termos de retenção.

A associação da capacidade de retenção de água ao conceito de seu potencial no solo tem gerado maior número de trabalhos visando a sua estimativa, bem como no sentido de desenvolver equipamentos que permitam a sua determinação.

O objetivo do presente trabalho é avaliar a performance de um novo novo instrumento, o HIDRO SAVER, para a determinação da lâmina de água, comparando-o aos consagrados métodos gravimétrico e da câmara de pressão. 


\section{REVISÃO DE LITERATURA}

\subsection{Conceitos Teóricos}

"Toda a matéria na natureza pode ser caracterizada quanto ao seu estado de energia. No sistema solo-planta-atmosfera os movimentos da água são muito lentos, e por isso a energia cinética neste sistema não deve ser considerada. A energia potencial, função da posição da água tomada em relação à referência ou a um estado considerado padrão, definido como sendo a água pura na superfície, à temperatura ambiente, se apresenta como a melhor forma de se analisar o seu grau de energia" (REICHARDT, 1985).

“A força de atração da matriz do solo sobre a água (adsorção) provoca o surgimento do potencial matricial $(\psi \mathrm{m})$. A presença de sais dissolvidos na água resulta

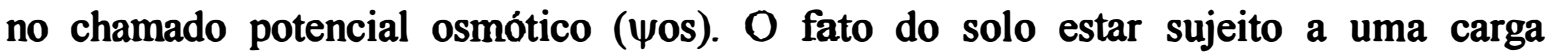
hidráulica ou a uma tensão, promove um estado de energia que causa o surgimento do potencial de pressão ( $\psi p)$. Finalmente, a ação do campo gravitacional terrestre gera em todo corpo nele presente um potencial gravitacional $(\psi \mathrm{g})$. O potencial total da água no solo $(\psi)$ é considerado como a integral de todas as componentes diferenciais que agem no sistema, mas em muitos casos a adição de outros componentes são ainda necessários". (REICHARDT, 1975).

O componente matricial $(\psi \mathrm{m})$ da água no solo, ao contrário do potencial gravitacional e do potencial de pressão, não pode ser calculado deterministicamente devido à sua complexidade e à heterogeneidade dos fatores envolvidos, mas pode ser medida experimentalmente por meio de tensiômetros, ou instrumentos de sucção, ou de 
pressão. Esta componente resulta de forças de adsorção (observada em forma de capa de hidratação sobre a superfície das partículas) e da coesão ( força de atração entre moléculas de igual natureza). As forças de adsorção, de adesão e de coesão, agindo em conjunto nos poros do solo dão origem ao fenômeno da capilaridade. Quando o solo está muito úmido as forças capilares são mais importantes mas, à medida que a umidade decresce as forças adsortivas vão tomando seu lugar (REICHARDT, 1985).

Numa amostra homogênea de solo, cada valor do potencial mátrico corresponde a uma certa umidade volumétrica $(\theta)$. A representação gráfica do potencial mátrico $(\psi \mathrm{m})$ em função da umidade volumétrica $(\theta)$ é uma característica da amostra de solo e é chamada de curva característica da umidade ou curva da retenção. Esta curva passa a depender do arranjo, da textura e estrutura do solo que por sua vez determinam as dimensões dos poros onde a água fica armazenada. Em situações de altos teores de água, onde os fenômenos capilares são de maior importância, o potencial mátrico ( $(\Psi \mathrm{m})$ passa a ser basicamente uma função de distribuição de porosidade do solo e da densidade global. Podemos observar diferenças nas curvas características da umidade do solo obtidas por secamento e por molhamento para solos tipicamente argilosos ou arenosos, e também para um solo qualquer com estrutura natural ou compactada (REICHARDT, 1975; MEDINA \& GROHMANN, 1962 e 1966; MARCOS, 1968; SCARDUA, 1972).

Com a obtenção do valor de umidade em volume $(\theta)$ de um solo e fazendo uso de sua curva característica, podemos estimar o potencial mátrico e viceversa. Se mantivermos a geometria da amostra do solo durante o tempo, a curva característica é considerada única para o procedimento experimental na qual foi gerada, pois ainda não existe uma teoria satisfatória para sua obtenção que pode ser por "secamento" ou "molhamento". No secamento, método usado na maioria dos trabalhos, toma-se uma amostra de terra inicialmente saturada de água e submete-se à tensões cada vez maiores, fazendo medidas sucessivas de umidade $(\theta)$ em função da tensão $(\psi m)$. No molhamento, toma-se uma amostra inicialmente seca ao ar e permite-se seu gradual molhamento com redução da tensão. Os dois métodos originam curvas contínuas que 
são diferentes para uma mesma amostra. A esta diferença denomina-se histerese (REICHARDT, 1985; PHILLIPS, 1960; MILLER, 1974; TOPP, 1979).

A capacidade de armazenamento de água no solo está diretamente relacionada à distribuição dimensional dos seus poros. A porosidade do solo é condicionada pela sua textura e pelo seu estado de agregação. A interação trifásica, sólido-líquido-gás, promove, no interior do perfil, o surgimento dos fenômenos de adsorção e capilaridade, que se constituem nas forças que definem o grau e a intensidade da dinâmica da água no solo.(CASSEL \& NIELSEN, 1986).

Sob condições normais, num elemento de solo, as três fases variam, sendo que, para efeitos práticos, a parte sólida pode ser considerada constante em relação à amplitude de variação das fases líquida e gasosa, cuja variações são inversamente proporcionais entre si, e resultantes da interação com a atmosfera e com as plantas, no decorrer do tempo.

A variação da quantidade de água armazenada no perfil de solo sofre, também, influência de fatores tais como: a taxa de evaporação e de transpiração local, o tipo de cultura estabelecida, a densidade de plantio, a profundidade das raízes, a natureza do perfil do solo em profundidade e dos impedimentos à drenagem (CASSEL \& NIELSEN, 1986).

A dificuldade de se estimar ou medir a quantidade de água, que, através de um equilíbrio dinâmico, permanece por mais tempo no solo, tem gerado metodologias empíricas para a estimativa desse parâmetro, as quais apresentam controvérsias quanto à sua generalização para os diferentes tipos de solo (REICHARDT, 1985).

VEIHMEYER e HENDRICKSON (1931) formularam o conceito de capacidade de campo, e a completaram relacionando-a posteriormente ao estado da energia da água neste ponto, como sendo a tensão de 0,3 atm (VEIHMEYER e HENDRICKSON, 1949). Esses dois trabalhos, juntamente com o de COLMAN (1947), serviram de base para a divulgação e a utilização do termo "capacidade de campo", e esta associação gerou um grande número de trabalhos sobre $o$ assunto. 
Segundo o Comitê de Terminologia de Física de Solo, da Sociedade Internacional de Física de Solo, "o potencial total da água no solo é a quantidade de trabalho que deve ser realizada por unidade de massa, volume ou peso, para transportar, reversível e isotermicamente, uma quantidade infinitesimal de água desde um reservatório de água pura num nível determinado e sob pressão atmosférica (estado de referência), para um ponto considerado dentro do sistema solo - planta - atmosfera".

Os processos mais conhecidos para a estimativa da umidade do solo, incluem métodos gravimétricos, eletrométricos e tensiométricos (SHAW \& ARBLE, 1959) e, mais recentemente, o método de moderação de nêutrons tem sido aplicado com sucesso (REICHARDT 1985). Por outro lado, o método termogravimétrico era o único cujo processo é determinístico, e como tal, é tomado como padrão para aferir os demais métodos.

Dentre os métodos rápidos, BOUYOUCOS $(1926,1927,1928)$ estudou largamente a utilização da higroscopicidade dos álcoois metílico e etílico, para estimativa da umidade de amostras de solo. $\mathrm{O}$ seu método é, entretanto, inadequado para as determinações em campo, embora apresente rapidez e precisão. A eliminação da umidade de uma amostra de solo, utilizando o calor produzido pela queima do álcool, foi também apresentada por BOUYOUCOS (1937). O princípio do seu método é extrair a água da amostra de solo com álcool e depois evaporá-la pela queima do álcool. $\mathrm{O}$ calor produzido ajuda a secar completamente a amostra. Não é recomendado para solos com alto teor de matéria orgânica (mais de $11 \%$ ). Este método foi revisto e modificado por OGANESYAN (1958), que utilizando-se de um vasilhame comum de alumínio, conseguiu um aquecimento mais uniforme e uma maior precisão nas medidas. 
2. 2. Métodos de medida da umidade do solo.

\section{2. 1. Gravimetria}

Consiste em tomar uma amostra, inicialmente úmida, determinar o seu peso (massa) úmida, depois levá-la à estufa a temperatura de 105 a $110^{\circ} \mathrm{C}$, por 24 a 48 horas, a fim de que a água possa evaporar completamente. Neste período devem ser feitas várias pesagens para assegurar que a amostra atingiu um peso constante, quando então deve ser levada ao dessecador para que resfrie mas que não absorva umidade do ar, e só então, deve-se tomar o peso (massa) seco. A diferença entre o peso úmido e o peso seco corresponde à massa de água que foi retirada da amostra, e este valor é normalmente dividido pela massa do solo seco resultando num razão adimensional $U$ ( $g$ de água /g de solo). Usualmente multiplica-se U por 100 para expressar a umidade em percentual (REICHARDT, 1975).

$$
\mathrm{U}=(\mathrm{PSU}-\mathrm{PSS}) / \mathrm{PSS} \text { ou } \theta=\mathrm{Da}(\mathrm{Mu}-\mathrm{Ms}) / \mathrm{Ms} .100
$$

onde: $\mathrm{U} \rightarrow$ é a umidade na base de massa;

Mu ou PSU $\rightarrow$ é o peso da amostra úmida em g;

Ms ou PSS $\rightarrow$ é o peso da amostra seca em $g$;

$\mathrm{Da} \rightarrow$ é a densidade global do solo em g/cm3.

Assim, o método gravimétrico era, até então, o único método cuja base teórica é determinística e por isso mesmo ainda é tomado como padrão para aferir os outros métodos.

Vários fatores podem interferir na precisão de um método. TAYLOR (1955), citado por GARDNER (1965), achou variações de 17 e $20 \%$ nas medições por gravimetria, do conteúdo de água em amostras de solo em áreas sob irrigação, por método de sulcos e aspersão, respectivamente. 
O método de campo mais preciso e prático para a determinação da umidade do solo, segundo estudos comparativos feitos por KELLEY e HUNTER (1946), é o que utiliza o tensiômetro. Estes autores, estudaram quatro métodos: o de blocos de absorção (gravimétrico), o de blocos de Bouyoucos (eletrométrico), o de unidades térmicas e o do tensiômetro. Para MORETTI FILHO (1962), nos limites de $850 \mathrm{~cm}$ de tensão de água, obtêm-se os melhores resultados com o tensiômetro e que, para tensões acima de uma atmosfera, e quando não há grande quantidade de sais na solução, os blocos de Bouyoucos apresentam a vantagem de, uma vez instalados e calibrados, dispensarem a amostragem, já que as leituras expressam a umidade atual do solo, à profundidade na qual está instalado.

\section{2. 2. Membrana de pressão.}

Consta de uma câmara de pressão ligada à atmosfera por intermédio de uma placa (ou membrana de celofane) sobre a qual é colocada a amostra de solo. A parte inferior à placa acha-se sempre sob pressão atmosférica (REICHARDT 1975, 1985).

A amostra de solo é colocada sobre a placa e saturada com água por um período de 24h. Em seguida, aplica-se uma pressão $P_{1}$ (de 0,1 a 2 atm para um tipo de instrumento e de 1 a 20 atm para outro) à câmara. Devido a esta pressão a água é retirada do solo até que o equilíbrio se estabeleça e, nestas condições, o solo terá um teor de água $\theta$ retido no solo a uma pressão $\mathrm{P} 1$.

Para este mesmo autor a limitação destes instrumentos está na placa ou membrana porosa. No intervalo de pressões $P_{i}$ utilizado, a membrana (quando molhada) deve ser impermeável ao ar e permeável à água. Ela é permeável à água devido à continuidade dos capilares de água e impermeável ao ar porque a pressão $\mathrm{P}_{\mathrm{i}}$ não é suficiente para eliminar a água dos capilares. Existem dois tipos de aparelhos, um denominado "câmara de pressão", para pressões $0<\mathrm{P}_{\mathrm{i}}<2$ atm e outro, de alta 
microporosidade, denominado de placa ou membrana de RICHARDS, para pressões $1<$ $\mathrm{P}_{\mathrm{i}}<20 \mathrm{~atm}$.

\section{2. Funil de placa porosa.}

Consta de um funil ao qual se acha adaptada uma placa porosa. Este instrumento é utilizado para potenciais baixos, de 0 a $400 \mathrm{~cm}$, aproximadamente. Estes valores baixos são limitados pela altura do arranjo e pela porosidade da placa que, geralmente, permite a passagem de ar para $h>400 \mathrm{~cm}$ (REICHARDT 1985, 1975).

\section{2. 4. Tensiômetro.}

Segundo RICHARDS \& GARDNER (1936), o tensiômetro é a combinação de uma membrana porosa e um medidor de pressão, que serve para medida da tensão capilar ou a energia com que a água está retida pelo solo. $\mathrm{O}$ termo energia pode ser expresso pF, que é definido como logaritmo da altura da coluna de água (em $\mathrm{cm}$ ) equivalente à tensão da água no solo ou de um potencial (energia por unidade de massa ou volume). Por facilidade de medida e cálculo, a energia por unidade de peso é a de maior emprego em cálculos de balanço hídrico, irrigação, etc., pois é representada por uma coluna de água (ca) (LIBARDI, 1984; ROSE, 1966; REICHARDT, 1975).

$\mathrm{O}$ tensiômetro convencional consiste numa cápsula porosa conectada a um manômetro por meio de um tubo que possui, em seu interior, uma coluna contínua de água, unindo a cápsula de cerâmica ao dispositivo de medida que pode ser um simples tubo em " $u$ " de água ou mercúrio. Outros modelos podem vir equipados com manômetro para leitura direta (RICHARDS \& GARDNER, 1936).

O tensiômetro convencional com manômetro de mercúrio é um instrumento que, quando em contato com o solo, a água do seu interior está à pressão atmosférica. Quando a sua cápsula entra em contato com a solução do solo o equilíbrio tende a estabelecer-se. A solução do solo estando sob tensão, exerce uma sucção sobre a cápsula do instrumento e dele retira certa quantidade de água causando a queda de sua pressão interna. Como o instrumento é vedado, a coluna de mercúrio h do manômetro, 
cresce, indicando a tensão interna da água. Estabelecido o equilíbrio, o potencial da água dentro do tensiômetro é igual ao potencial da água do solo e assim h é uma medida direta do potencial mátrico ( $\psi \mathrm{m})$ ") (REICHARDT, 1975).

“A cápsula do tensiômetro geralmente é de cerâmica, para que resista a pressão e seja porosa e para que permita que a água e solutos passem livremente, mas impeça a passagem de partículas de solo e do ar. Ela funcionará como uma membrana permeável, permitindo que a água dentro do tensiômetro fique com a mesma composição e concentração da solução do solo e, isso implica que o tensiômetro não mede potencial osmótico, a menos que seja equipado com algum sensor especial para sais" (OLITTA, 1974).

"O intervalo de funcionamento do tensiômetro é limitado, e há uma tensão de aproximadamente $\mathbf{0 , 8}$ atm quando ocorrerá uma ruptura da coluna de água ou entrada de ar no sistema, igualando a pressão interna do tensiômetro à pressão atmosférica" (HILLEL, 1971). "Para solos arenosos o intervalo de funcionamento do tensiômetro pode cobrir até $90 \%$ da água disponível, o que não ocorre em solos argilosos, por exemplo, e um solo com $42 \%$ de montmorilonita a tensão pode variar de 200 a $800 \mathrm{~cm}$ de coluna de água para apenas 1\% de variação de umidade" (ABELE et al., 1979).

"O tensiômetro apresenta limitações quanto ao tempo de resposta ás variações da umidade do solo, atribuídas a fatores como a condutância hidráulica (K) da cápsula" (KLUTE \& GARDNER, 1962), a sensibilidade do dispositivo de medida (S) (RICHARDS \& O'NEAL, 1937) e a condutividade hidráulica do próprio solo (TOWER, 1980).

Os tensiômetros possuem inúmeras vantagens no seu uso para estimativa do potencial mátrico do solo (SCHMUGGE et al., 1980), e seu uso só não é intenso porque são caros, facilmente danificáveis, e requerem uma manutenção cuidadosa. Os tensiômetros equipados com manômetros de mercúrio não são caros, são sensíveis, mas requerem cuidado no manuseio do mercúrio além de manutenção constante em nível de campo. Com o objetivo de minimizar os custos e eliminar o uso do mercúrio, PAES DE 
CAMARGO et al. (1982) desenvolveram e testaram um tensiômetro em tubo transparente (chamando-o de tensiômetro simples de leitura direta), baseado na expansão de uma câmara de ar, deixada propositadamente dentro do tensiômetro e cuja variação foi correlacionada com a tensão matricial no solo estimada por um tensiômetro aneróide adjacente. VILLA NOVA et al. (1989) propuseram um modelo matemático teórico para este mesmo tensiômetro (chamando-o de tensiômetro de bolha de ar), onde estudaram as variáveis climáticas que interagem sobre o mesmo. VILLA NOVA et al. (1992) testaram o modelo e constataram a eficiência do instrumento em nível de laboratório.

\section{2. 5. Moderação de nêutrons.}

Utiliza-se de uma fonte selada de nêutrons rápidos (energia em torno de 2 $\mathrm{MeV}$ ) e um detetor de nêutrons sensível somente aos nêutrons termalizados (energia em torno de $0.025 \mathrm{eV}$ ). A energia média perdida é muito maior nas colisões de nêutrons com átomos de baixo peso atômico do que nas colisões envolvendo átomos mais pesados. O hidrogênio é o elemento de mais baixo peso atômico em solos normais e está sempre presente em quantidade apreciável, portanto, este elemento termaliza os nêutrons rápidos mais efetivamente do que qualquer outro elemento no solo. $\mathrm{O}$ hidrogênio no solo está presente quase que inteiramente na forma de água e por isso a densidade da nuvem de nêutrons térmicos, resultante das colisões de nêutrons rápidos com o hidrogênio, é função do teor de água do solo, independente do estado fisico em que se encontra a própria água, (SALATI, 1960; BARROS FERRAZ, 1968; JENSEN \& SOMER, 1967; e CRUCIANI, 1971).

A grande limitação para o uso da sonda de nêutrons deve-se, dentre outros fatores, à necessidade de estabelecer a curva de calibração que relaciona entre si as respostas da sonda e o teor de água do solo (ENCARNAÇÃO, 1988), simplificou sobremaneira a obtenção da curva de calibração para a sonda de nêutrons ao desenvolver um "sistema fechado para calibração de sonda de nêutrons em laboratório" e um outro "sistema modulado de superficie para calibração de sonda de nêutrons no 
campo" que dispensa as paredes impermeáveis exigidas pelos métodos anteriores (CARNEIRO e De JONG 1986). 


\section{MATERIAL E MÉTODOS}

\section{1. Área experimental e clima.}

O experimento de campo foi conduzido na Estação Experimental de Cana-de-açúcar do Carpina - PE, localizada na zona úmida costeira do estado de Pernambuco, mais particularmente na micro-região homogênea da Mata Setentrional Pernambucana, município do Carpina. Coordenadas de posição: latitude $7^{0} 47^{\prime} \mathrm{Sul}$, longitude $35^{\circ} 15^{\prime}$ WGr e altitude de $178 \mathrm{~m}$. O clima desta região é do tipo As, segundo KOEPPEN (tropical chuvoso, com verão seco), com temperatura média anual da ordem de $24,3{ }^{\circ} \mathrm{C}$, com precipitação pluviométrica total média anual de $1261,5 \mathrm{~mm}$ e o período mais seco posicionado entre outubro e janeiro (KOFFLER, 1986).

\section{2. Solo.}

Segundo o "Mapa Exploratório de Reconhecimento de Solos do Estado de Pernambuco", a área está compreendida na unidade LVe 7, Latossolo VermelhoAmarelo Eutrófico húmico textura argilosa, fase floresta subcaducifólia, relevo plano e suave ondulado. São solos que possuem como material de origem os sedimentos do Grupo Barreiras, apresentam boa profundidade, boa drenagem e pedregosidade ausente (JACOMINE et al., 1973).

A unidade de solo sobre a qual os experimentos de campo esta classificada como Podzólico Amarelo Distrófico com fragipan A proeminente, textura média /argilosa, fase floresta subcaducifólia; na primeira parcela o relevo é plano e na segunda o relevo é suave ondulado (ALVES, 1994). 


\section{3. Parcela experimental e medições de campo.}

Em cada perfil de solo foi instalada uma parcela de $1,00 \times 1,00 \mathrm{~m},\left(1 \mathrm{~m}^{2}\right)$ limitada por uma estrutura de chapa de ferro com altura de $0,30 \mathrm{~m}$, que foi cravada na superfície de modo a penetrar $0,05 \mathrm{~m}$ no solo, a fim de manter uma lâmina de água de $0,15 \mathrm{~m}$ de altura homogeneizada sobre a parcela (Figura 1).

A parcela foi inundada de forma lenta e gradual até a formação de uma lâmina de água com $0,15 \mathrm{~m}$ de altura em toda a área delimitada.

Após a inundação, as parcelas foram cobertas com plástico para evitar as perdas de água por evaporação. Assim, as parcelas foram deixadas a drenar por 3 dias, e foram efetuadas leitura nos tensiômetros para detectar o momento de equilíbrio da umidade no perfil.

\section{3. 1. Instrumentos de medição.}

\section{3. 1. 1. Potencial da água no solo}

Foram utilizados tensiômetros com escalas em centibar (com divisão a cada 2 centibares, equivalente a $20 \mathrm{~cm}_{2} \mathrm{O}$, ou seja, 1 bar $\cong 1$ atm) para medir o potencial matricial da água no solo.

Os tensiômetros foram testados e calibrados no laboratório de solos da UFRPE. As cápsulas foram mergulhadas em baldes com água por 24 horas até que o nível de água, no interior do tubo dos tensiômetros, fosse igual em nívelda água no interior dos baldes. Este procedimento, além de saturar as cápsulas também expulsa o ar do interior dos mesmos, reduzindo o trabalho de refluxo para extrair o ar, e também testa a permeabilidade das cápsula dos tensiômetros (Figura 2).

Logo que o equilibrio foi atingido, os tensiômetros foram cheios com água até o limite e com uma bomba de vácuo retiraram-se as bolhas de ar dissolvidas no 
seu interior. Após serem fechadas na parte superior, as cápsulas foram expostas ao ar para testar o funcionamento e também para regular a marcação dos manômetros.

Com os tensiômetros cheios de água, foram mantidas as cápsulas mergulhadas no balde com água e, então, calibrados os manômetros para marcarem

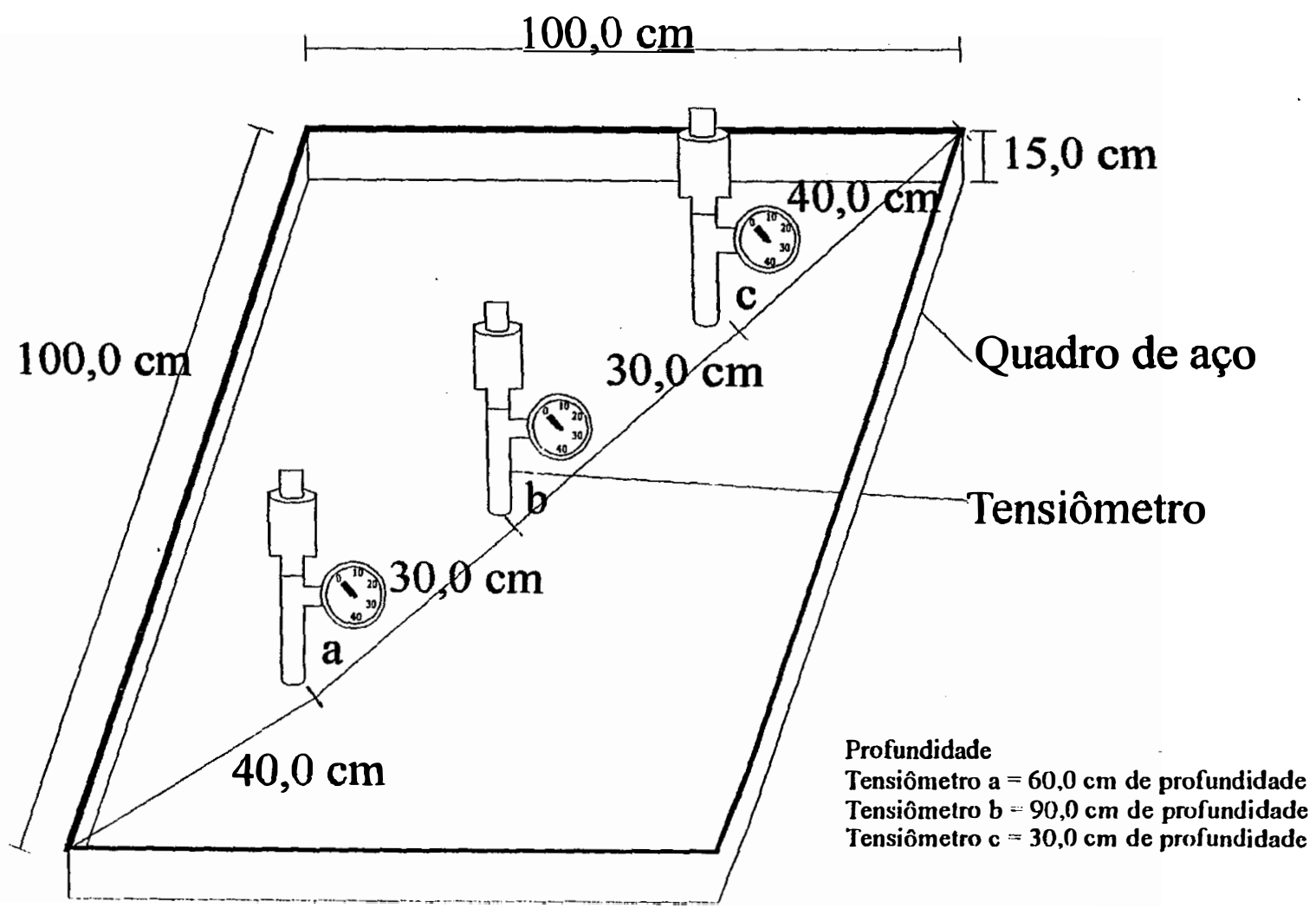

Fig. 1 - Parcela de campo. 


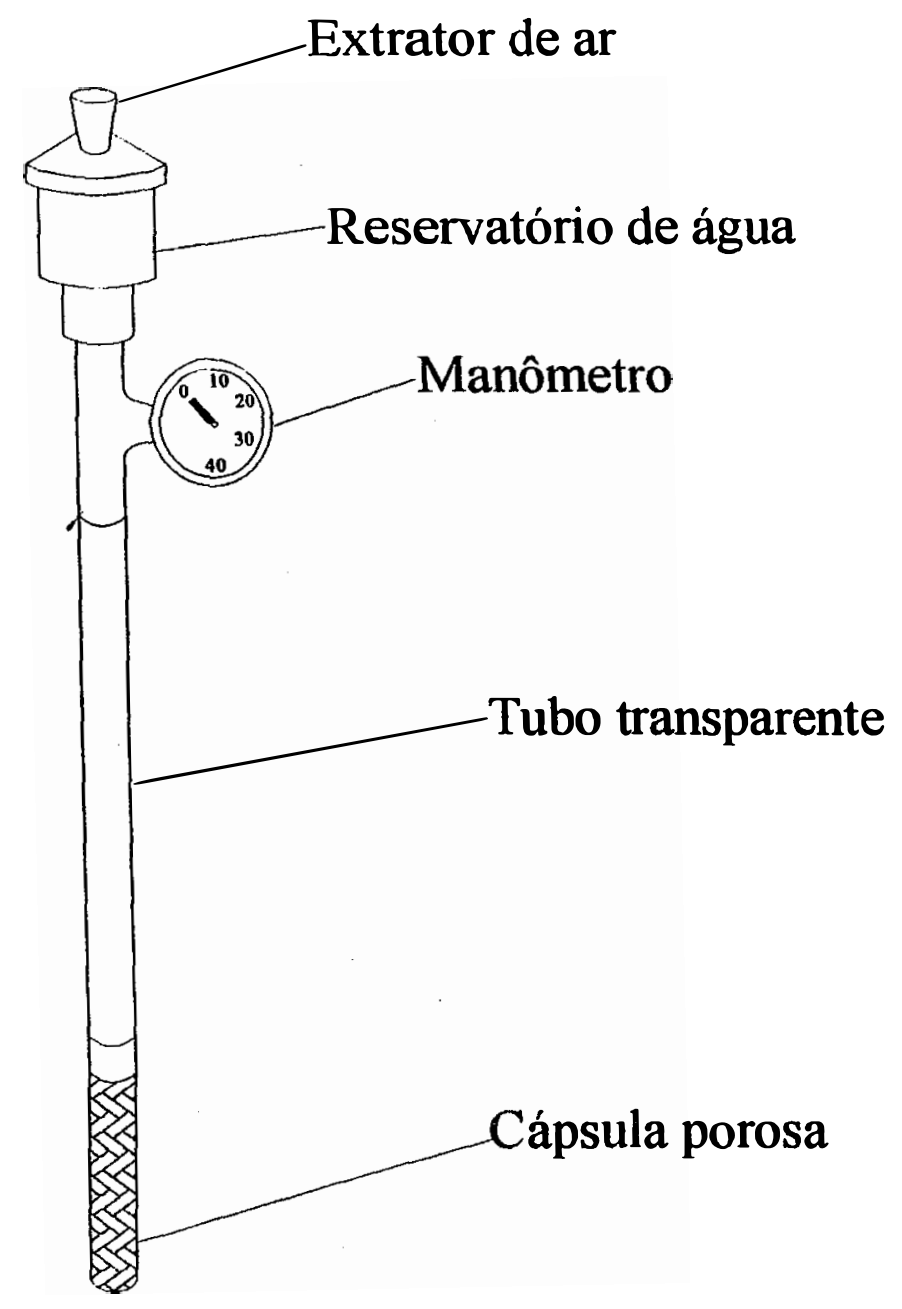

Fig. 2 - Tensiômetro de manômetro com escala em centibar. (relação 1 centibar $\cong 1 \mathrm{~atm}$ ) $(0,02$ centibar $\cong 20 \mathrm{~cm} \mathrm{c.a})$ 
zero. Neste caso, a coluna de água do instrumento não foi considerada nas leituras de superfície, uma vez que, com a calibração do manômetro em zero, o seu efeito sobre o registro será, neste caso, nulo, e a leitura no campo representará diretamente o potencial matricial da água no solo.

Após o teste e calibração, os tensiômetros foram instalados, três em cada parcela, posicionados em linha reta, transversal à parcela, mantendo-se uma distância de $0,30 \mathrm{~m}$ um do outro e alterando a profundidade em $0,30,0,60$ e $0,90 \mathrm{~m}$.

Os valores obtidos no manômetro na superfície do solo correspondem, diretamente, ao potencial matricial da água no solo ( $\psi \mathrm{m})$, expresso em centibares que foram transformados para $\mathrm{cm}$ de coluna de água, segundo a relação $1 \mathrm{bar}=1 \mathrm{~atm}$.

A instalação dos tensiômetros foi feita em orificios abertos com trado de diâmetro igual ao diâmetro da cápsula porosa, tendo-se o cuidado de propiciar um bom contato entre a cápsula e o solo, e isto foi viabilizado derramando-se água logo após a introdução do instrumento nos orifícios. Esta técnica mostrou-se válida na ocasião das amostragens, verificando-se um bom contato solo/cápsula.

\section{3. 1. 2. O HIDRO SAVER.}

Esse instrumento foi desenvolvido no Brasil, com matéria prima nacional e foi premiado, em segundo lugar, no $7^{\circ}$ Concurso do Inventor Nacional, promovido pelo Centro Federal de Educação e Tecnologia Celso Suckow da Fonseca, CEFET, em 1989. O instrumento está devidamente registrado no Instituto Nacional da Propriedade Industrial (INPI), carta patente $n^{0} 8.903 .754$, com o nome de "HIDROCAPACITOR", cuja patente de invenção pertence ao próprio inventor, Fernando Antônio Franco da Encarnação. Segundo o relatório descritivo da patente de invenção, o Hidrocapacitor é um instrumento capaz de determinar a capacidade de armazenamento de água do solo a partir da própria capacidade hidroscópica da amostra, levando em consideração a natureza das partículas, o potencial de solubilidade de sais, o tamanho e a distribuição 
dos poros do solo, a expansibilidade das suas partículas, sua textura e estrutura, além do próprio teor de água da amostra.

\section{3. 1. 2. Descrição do instrumento.}

As figuras 3 e 4 mostram o posicionamento dos componentes do instrumento, em dois ângulos de visão: a figura 3 é uma visão lateral e a figura 4 mostra a distribuição dos componentes sobre a base. Conforme se pode inferir das figuras 3 e 4 , o Hidrocapacitor que, de agora em diante, será chamado de HIDRO SAVER é composto de uma base plana (1) e de um reservatório transparente de água (2) com uma escala graduada (3), para permitir a medida da variação do nível de água diretamente em $\mathrm{mm}$ (lâmina de água); um tubo flexível (4) que transfere cotas d'água do reservatório para a célula de distribuição (5), que é fixada no centro da mesa de recepção de amostras (6) e situada no interior do cilindro amostrador (7). Na parte superior da célula de distribuição (5), a água é mantida em nível constante e sob pressão atmosférica (potencial total próximo de zero). A carga hidráulica gerada pela altura da coluna d'água no interior da célula de distribuição (5) mantém o equilíbrio dinâmico do sistema de alimentação, tendo em vista que, no reservatório de água (2), existe um tubo de admissão de ar (12) que transfere a pressão atmosférica para um plano horizontal, tangente à parte superior da célula de distribuição (5). Dessa forma, a célula de distribuição (5) funciona como um lençol freático de nível constante. Um disco (10) é colocado na parte superior do cilindro de coleta de solo (9), através do qual, pode-se observar a mudança de coloração do solo promovida pela ascensão da frente de molhamento .

\section{3. 1. 2. 2. Arquitetura e dimensões.}

$O$ instrumento é composto por um suporte em " $U$ " (comprimento de $19,5 \mathrm{~mm} \times$ largura $100 \mathrm{~mm} \times$ altura $35 \mathrm{~mm}$ ) sobre o qual está fixada uma base cilíndrica ( $35 \mathrm{~mm}$ de altura por $40 \mathrm{~mm} \emptyset$ externo), que mantém na posição vertical uma torre de 
vidro $(365 \mathrm{~mm}$ de altura $\times 18 \mathrm{~mm} \varnothing$ externo $\times 14,5 \mathrm{~mm} \emptyset$ interno), com uma escala gravada de 0 a 20, em mm equivalentes (altura de lâmina d'água). A parte superior da torre serve de suporte para fixar um tubo de vidro $(370 \mathrm{~mm}$ de comprimento $\times 6,0 \mathrm{~mm} \varnothing$ externo $\times 3,0 \mathrm{~mm} \emptyset$ interno) que se prolonga pelo centro da torre até o seu limite

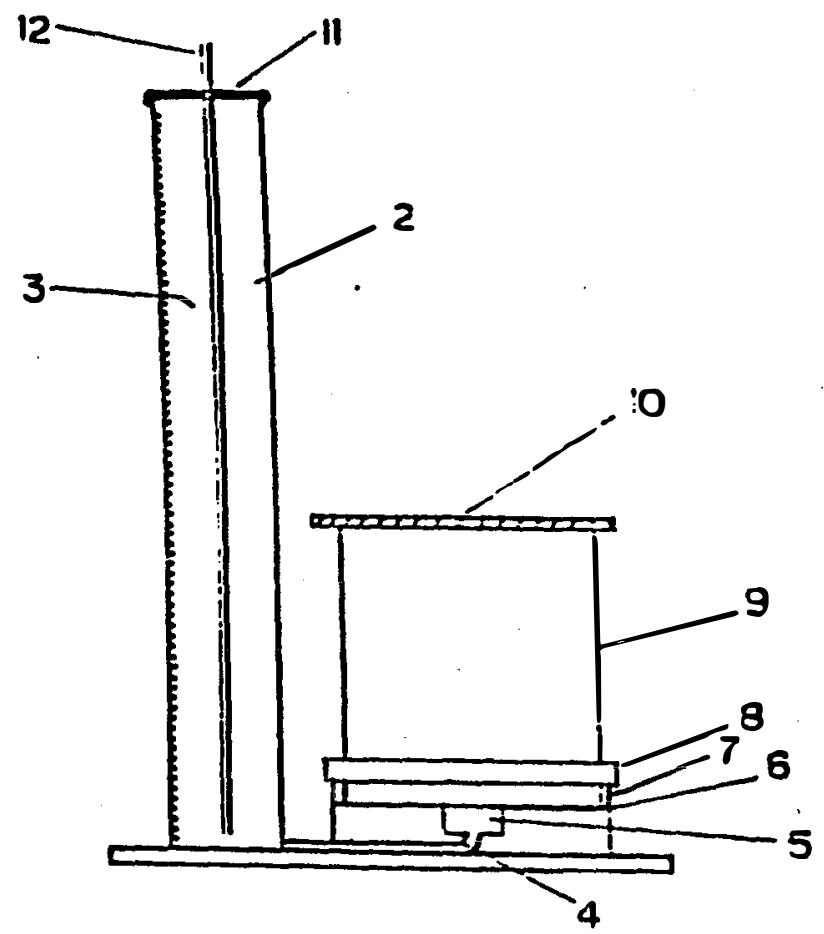

Fig. 3 - Visão lateral em corte do HIDRO SAVER. 


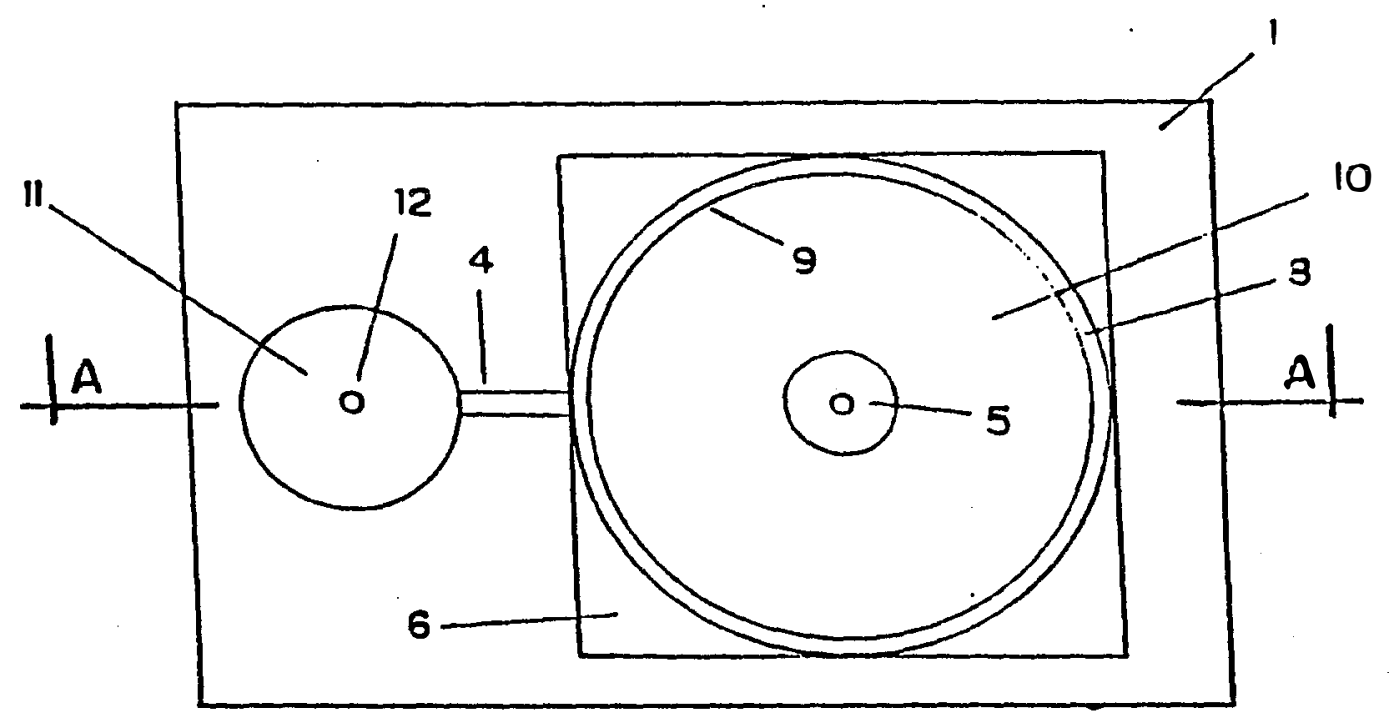

Fig. 4 - Distribuição dos componentes sobre a base do HIDRO SAVER.

de comprimento. A torre é encaixada no anel de borracha colocado na parte superior da base.

Na parte interna e inferior da base, um tubo $(25,0 \mathrm{~mm}$ de comprimento $\mathrm{x}$ $5,0 \mathrm{~mm} \emptyset$ externo e $3,0 \mathrm{~mm} \varnothing$ interno) permite o encaixe de uma mangueira flexível ( $250 \mathrm{~mm}$ de comprimento x 6,0 Ø externo e $3,0 \mathrm{~mm} \emptyset$ interno), por onde o fluxo d'água é conduzido até à mesa de recepção de amostras $(30,1 \mathrm{~mm}$ de altura $\times 65 \mathrm{~mm}$ de $\varnothing$ externo e $53,5 \mathrm{~mm} \emptyset$ interno), no centro da qual uma célula de distribuição de água $(15,0 \mathrm{~mm}$ de altura $\times 22,0 \mathrm{~mm}$ de $\emptyset$ externo e $16,5 \mathrm{~mm} \emptyset$ interno $)$ tem, na sua parte central e inferior, um tubo $(10,0 \mathrm{~mm}$ de comprimento $\times 3,0 \mathrm{~mm} \varnothing$ externo e $2,0 \mathrm{~mm} \varnothing$ interno) onde se acopla a mangueira que vem da base. Dentro da célula de distribuição de água uma esponja de borracha $(16,0 \mathrm{~mm}$ de comprimento $\times 20,0 \mathrm{~mm}$ de diâmetro externo) é colocada, para evitar que o solo caia no seu interior e obstrua a mangueira. 
A parte superior da mesa foi projetada para permitir um perfeito encaixe com o cilindro amostrador de solo confeccionado em alumínio (padrão 33,0mm de altura $\times 50,5 \mathrm{~mm} \varnothing$ externo e 48,5mm $\varnothing$ interno) cortado em todo perímetro na forma de bisel para evitar a compactação do solo no momento da coleta das amostras.

Sobre o cilindro amostrador de solo, por ocasião da utilização do instrumento para determinação da lâmina de água complementar, se faz necessário colocar um disco transparente $(3,0 \mathrm{~mm}$ de espessura $\times 53,0 \mathrm{~mm} \emptyset)$ para evitar perdas por evaporação durante o processo de determinação. No caso da utilização do HIDRO SAVER para medir a demanda atmosférica o disco plástico não deve ser colocado sobre a amostra nem sobre a célula da distribuição de água (Figura 5).

\section{3. 1. 2. Base teórica de funcionamento.}

A água, independentemente do seu estado físico, move-se sempre em resposta a um gradiente de potencial hidráulico $\mathrm{H}$ nos diferentes pontos dentro do sistema considerado. Este movimento se dá no sentido do decréscimo do potencial $\mathrm{H}$, isto é, a água move-se do ponto de maior potencial para pontos de menor potencial.

Define-se então o potencial hidráulico $\mathrm{H}$, que é o potencial total $\psi$ sem a inclusão do potencial osmótico. O potencial total da água em dado estado $\psi_{i}$ dificilmente pode ser determinado de forma absoluta. Determina-se então a sua diferença entre um estado tomado como padrão e o referido estado no sistema.

Toma-se como padrão o estado no qual o sistema água acha-se em condições normais de temperatura $(\mathrm{T})$ e pressão $(\mathrm{Pe})$, livre de sais e outros solutos, com a interface líquido-gás plana, situado em um referencial de posição dado. A este estado é atribuído o valor arbitrário de potencial total igual a zero $\psi_{0}=0$. Assim, o potencial $\psi_{\mathrm{i}}$ da água em dado estado no sistema é dado por: 


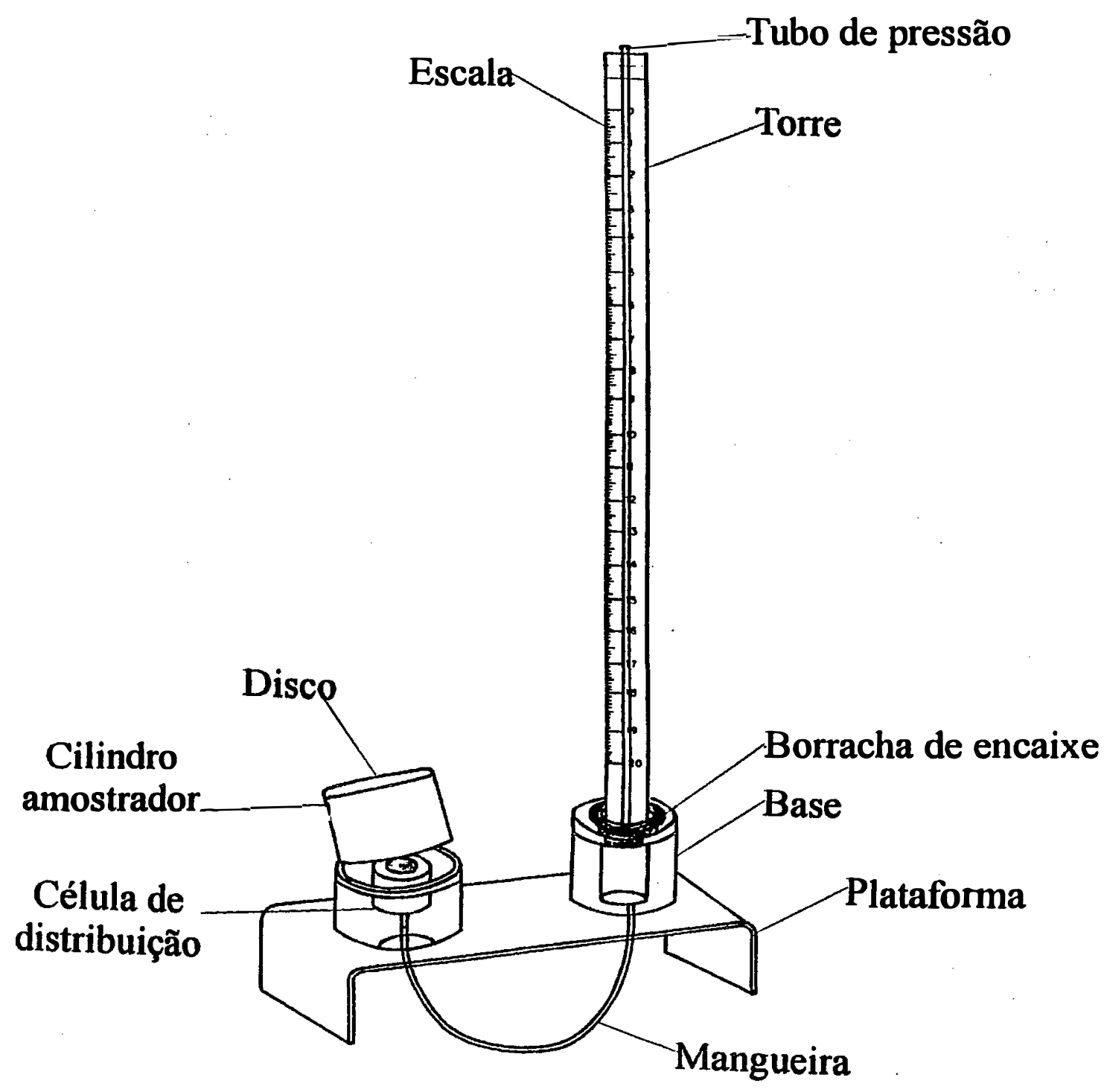

Fig. 5 - O Hidro Saver pronto para o uso. 


$$
\Delta \psi=\int_{\psi_{0}}^{\psi_{1}} \mathrm{~d} \psi=\left|\psi_{i}-\psi_{0}\right|=\psi_{i}
$$

ou ainda:

$$
\psi_{i}=\int_{T_{0}}^{T_{i}}-\mathrm{sdT}+\int_{P_{0}}^{P_{t}} \operatorname{vdP}+\int_{0}^{z_{1}} \operatorname{gdz}+\int_{00}^{n_{i}} \mu \mathrm{dn}+\int_{\theta_{s}}^{\theta_{i}} \operatorname{cod} \theta
$$

A equação (2) nos mostra que o potencial total da água é a soma de cinco componentes: térmico, de pressão, gravitacional, osmótico e matricial. Como alguns desses potenciais têm efeitos desprezíveis sobre o movimento da água no solo e, particularmente, no caso do HIDRO SAVER, onde o processo se dá isobárica e isotermicamente, os componentes térmico e de pressão podem ser retirados da equação (2) que fica entåo:

$$
\psi_{i}=\int_{0}^{z_{t}} \operatorname{gdz}+\int_{0}^{n_{i}} \mu \mathrm{dn}+\int_{\theta_{s}}^{\theta_{t}} \omega \mathrm{d} \theta
$$

Quando não existem membranas, os solutos movem-se com a água $\mathrm{e}$ mesmo na existência de diferenças de potencial osmótico de uma região para outra, o movimento de água é desprezível; os “sais" é que se movem e o equilíbrio é atingido. Por isso, no caso do movimento de água na fase líquida sem a presença de membranas para efeito de quantificação do movimento, o potencial total da água não inclui o componente osmótico (mesmo sendo ele não desprezível).

Nestas condições, a equação (3) se simplifica em:

$$
\psi_{1}=\int_{0}^{z_{1}} \mathrm{gdz}+\int_{\theta}^{\theta_{1}} \omega \mathrm{d} \theta
$$

ou

$$
\psi=H=\psi_{\mathrm{g}}+\psi_{\mathrm{m}}
$$


Onde $\mathrm{H}$ é o potencial hidráulico em $\mathrm{cm}$ ca, $\psi_{\mathrm{g}}$ é o componente gravitacional em cm ca, e $\psi_{\mathrm{m}} 0$ potencial matricial em $\mathrm{cm}$ ca.

No HIDRO SAVER, o seu princípio de funcionamento é respaldado na equação (3), uma vez que o instrumento funciona como um integralizador a tempo real. No momento em que a amostra entra em contato com a célula de distribuição, cada componente da equação (3) é contemplado e pode exercer plenamente os seus efeitos individualizados ou até mesmo os seus efeitos interrelacionados tomados em conjunto. Ao final do processo, o que se obtém na leitura do instrumento é o resultado de todas as forças e suas interações, que atuam sobre o armazenamento de água no solo expresso diretamente como milímetros de lâmina d'água.

\section{3. 1. 2. 4. Montagem e funcionamento.}

O HIDRO SAVER é um instrumento simples de montar e de usar. São as seguintes as etapas de preparação:

1. acoplar a torre à base, molhando antes a parte interna do anel de borracha da base;

2. passar a mangueira pelo orificio da plataforma e conectar a mangueira na parte inferior da mesa de recepção de amostras;

3. virar todo o instrumento para baixo inclinando-o cerca de $135^{\circ}$; acoplar a pisseta na parte superior da torre, pressionar para encher toda a torre; o instrumento estará carregado quando a água jorrar pelo centro da célula de distribuição;

(obs.: a coluna de água no tubo interno da torre é extremamente impor-tante para expulsar as bolhas de ar da mangueira e da célula de distribuição de água)

4. girar rapidamente o instrumento para a posição normal de funcionamento;

5. aguardar a estabilização;

6. com papel absorvente, zerar o nível de água na torre; 
7. colocar o cilindro de amostra e tampar com o disco;

8. aguardar que a freqüência de liberação de bolhas de ar, no interior da torre, esteja num intervalo de tempo de 30 s, uma da outra; e

9. fazer a leitura da variação do nível. O valor indicado é a lâmina complementar necessária.

Sob condições de saturação, apenas os componentes de pressão e gravitacional atuam sobre o movimento da água. Este último promove a drenagem interna do perfil até que forças capilares, em sentido contrário, sejam suficientemente intensas para igualarem-se à força gravitacional. Neste ponto, o solo encontra-se com a sua capacidade máxima de armazenamento de água e, $\psi_{\mathrm{t}}=\psi_{\mathrm{g}}+\psi_{\mathrm{p}}$. Nestas condições, o equilíbrio se estabelece e não há mais movimento, nem de drenagem, nem de ascensão capilar de água no perfíl. Esta situação, na prática, é muito raro ocorrer, pois a água está sempre em movimento dentro do perfil, devido à constante demanda do sistema.

No HIDRO SAVER, a célula de distribuição funciona como o elemento sensível onde o potencial total da água é mantido próximo a zero ou a um valor de potencial qualquer que se deseje; no presente trabalho, o valor foi de $0,5 \mathrm{~cm} \mathrm{H}_{2} \mathrm{O}$. Assim, quando uma amostra de solo é colocada sobre a mesa de recepção, um perfeito contato é estabelecido entre o solo e a célula de distribuição e, se o solo estiver com um nível de umidade que caracterize um estado de energia potencial menor que (no presente caso) $0,5 \mathrm{~cm} \mathrm{H}_{2} \mathrm{O}$, um fluxo de água da torre para a amostra do solo será estabelecido, sem restrições quanto à intensidade desse fluxo de água em direção à amostra. Cotas de água são transferida para a amostra em resposta ao gradiente de potencial total $\left(\psi_{\mathrm{x}}\right)$ $\partial \psi_{\mathrm{g}} / \partial \mathrm{z}$ até que $\psi_{\mathrm{t}}=\psi_{\mathrm{g}}$; quando, então, o fluxo cessar, a leitura na torre indicará a lâmina complementar necessária para que a amostra em questão atinja a sua capacidade máxima de retenção de umidade. Entenda-se que a lâmina d'água complementar representa o volume de água necessário para elevar a amostra de solo de um nível de umidade qualquer $\theta$, até a sua capacidade máxima de retenção de água $\theta$ máx, sem, no entanto, atingir à saturação $\theta_{\mathrm{s}}$. 
Considerando um caso particular, testado no presente trabalho, onde a amostra de solo tenha sido secada em estufa a $105^{\circ} \mathrm{C}$ ou seja, onde a umidade $\theta$ corresponde à umidade residual $\theta_{\mathrm{r}}$ a lâmina d'água indicada no HIDRO SAVER corresponderá diretamente à capacidade de armazenamento da amostra obtida, diretamente em lâmina equivalente de água. Levando em consideração todas as variações que possam contribuir para que esta condição seja atingida, ou seja:

$$
\mathrm{A}=\mathrm{Z} \int_{\theta_{\mathrm{r}}}^{\theta_{\max }} d \theta
$$

onde $\mathrm{Z}$ é a altura da amostra.

No caso da amostra em um nível de umidade qualquer, o resultado do HIDRO SAVER corresponderá à variação desde a umidade atual $\theta_{\mathrm{a}}$ até à umidade máxima de armazenamento. O HIDRO SAVER funciona como um fluxímetro para condição não saturada. É fácil perceber que a densidade de fluxo no interior da amostra não sofre restrição de nenhuma outra ordem, exceto do potencial total $\left(\psi_{\mathrm{t}}\right)$ que é a força que mantém o fluxo.

No HIDRO SAVER, o plano imediatamente abaixo da parte superior da frente de molhamento estará sempre com a área máxima disponível para o fluxo e, então, a condutividade hidráulica $K$ será sempre máxima $K_{0}$ pois $q$, assim como $K$, são funções de $\theta$, e $\theta$ é função do gradiente de potencial $\psi_{t}$.

Ao estabelecer-se o contato entre o solo contido no cilindro de coleta de solo e a célula de distribuição, haverá a formação de um gradiente de potencial por efeito das forças de coesão e adesão das partículas do solo (tal como a ascensão em um tubo capilar) que gera um fluxo d'água do reservatório para a célula de distribuição, a fim de restabelecer o equilíbrio inicial. Quando a amostra de solo atingir a sua capacidade máxima de armazenamento de água, o gradiente de potencial se anula e o fluxo d'água cessa. E a leitura, na escala do reservatório, indicará a lâmina d'água cedida ao solo. A escala do reservatório é graduada em milímetros de capacidade de 
contenção (lâmina d'água, $\mathrm{mm}$ ), sendo função da relação entre as áreas úteis do reservatório e do cilindro coletor de solo.

Quando a amostra é colocada na mesa, um perfeito contato é prontamente estabelecido entre a água da esponja e o solo contido no cilindro amostrador. Nestas condições, apenas duas situações podem ocorrer:

1. se o solo estiver com um nível de umidade correspondente à sua capacidade máxima de retenção, o nível de água na torre não varia, pois $\psi_{\mathrm{i}}=0 \mathrm{e}$, portanto, não há força para deslocar a água contida na célula de distribuição e o fluxo de água da torre para a amostra de solo, não se estabelece; $e$

2. se a amostra do solo estiver em um nível de umidade qualquer, abaixo da sua capacidade máxima de retenção, cotas d'água serão liberadas para a amostra até que o seu potencial total $\psi_{\mathrm{i}}=0$ tenda para zero ou, mais precisamente, para 0,5 cm $\mathrm{H} 2 \mathrm{O}$; as cotas de água transferidas para o solo fazem imediatamente variar o nível da torre; daí, uma simples leitura na escala é o suficiente para se determinar a lâmina complementar para a amostra de solo.

Nas determinações de umidade através deste instrumento, todas as variáveis são consideradas e o fluxo de água para a amostra cessa quando o potencial total tende a zero.

A equação matemática que mais se adequa ao funcionamento do HIDRO SAVER é a "equação da continuidade" uma vez que o conhecimento do fluxo q pela aplicação da equação de DARCY não é suficiente nos estudos que envolvem a dinâmica da água no solo.

\section{3. 2. Experimentos de campo.}

Foram feitas as leituras nos tensiômetros para detectar as variações do potencial matricial no campo. Quando os três tensiômetros apresentaram a mesma leitura (10 cbar) assumiu-se então que o perfil havia atingido o ponto de equilíbrio ou seja a "capacidade de campo". Daí, procedeu-se à retirada do solo em cilindros 
amostradores padrão do HIDRO SAVER, a fim de obterem-se amostras indeformadas para o cálculo da densidade aparente e da lâmina de água pelo método gravimétrico $\mathrm{e}$ pelo HDRO SAVER, para comparar os resultados.

Quando, baseado nas leituras dos tensiômetros, foi julgado que as variações das medidas de potencial total e, conseqüentemente, a umidade em campo não mais apresentavam variações perceptíveis, o plástico foi removido e toda a parcela foi cavada abrindo-se então uma trincheira que ocupou toda a área da parcela.

A escavação obedeceu ao seguinte esquema: toda a área da parcela foi subdividida em 30 planos subsequentes, de $0,033 \mathrm{~m}$ de altura, indo até a profundidade de $0,99 \mathrm{~m}$. De cada plano, foram retiradas 3 amostras indeformadas, em anéis volumétricos de $60,96 \mathrm{~cm}^{3}$, padrão do HIDRO SAVER $(3,3 \mathrm{~cm}$ de altura e $4,85 \mathrm{~cm}$ de diâmetro interno), alternando-se, a cada plano, o local da amostragem, a fim de ampliar a representatividade das amostras (Figura 6).

Os cilindros utilizados nesta arnostragem foram trabalhados no sentido de eliminar os excessos de solo. Para isto, cada cilindro passava dentro de uma cantoneira na forma de " $U$ ", com uma abertura de $0,033 \mathrm{~m}$. Este procedimento visou a não alterar o volume de solo coletado pois, freqüentemente, na eliminação do excesso de solo na borda do cilindro, pode-se alterar o volume de solo coletado.

3. 3. 2. 1. Medidas da umidade do solo pelo método gravimétrico e pelo HIDRO SAVER.

Graças à particularidade funcional do HIDRO SAVER, os dados relativos à umidade do solo foram determinados pelo método gravimétrico e pelo HIDRO SAVER simultaneamente, obedecendo-se ao seguinte procedimento:

As amostras coletadas no campo foram acondicionadas em latas de alumínio, vedadas com fita adesiva e levadas ao laboratório, onde foram pesadas com a umidade de campo (PSU); em seguida, cada amostra foi colocada no HIDRO SAVER para a determinação da lâmina d'água complementar (HSU); daí, as amostras foram levadas à estufa a $105^{\circ} \mathrm{C}$, por 48 horas; após a secagem determinou-se o peso seco 
Limitador da parcela

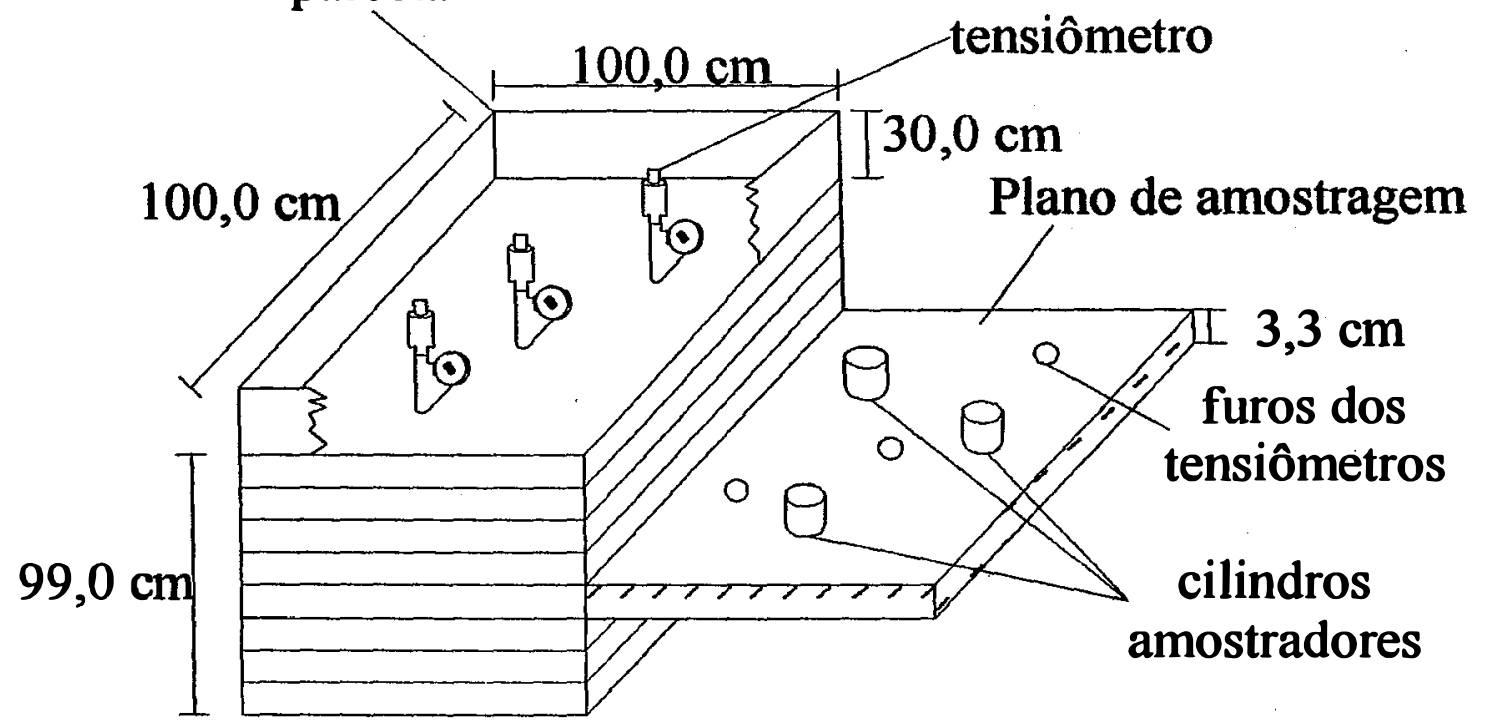

Fig. 6 - Esquema dos planos de amostragem nas parcelas de campo. 
(PSS); e, em seguida, as amostras secas foram colocadas no HIDRO SAVER para a determinação da capacidade máxima de retenção de água da amostra (HSS).

O mesmo procedimento foi adotado para os dois experimentos de campo, nos perfis I e II.

Com os valores do peso úmido e do peso seco das amostras, calculou-se, inicialmente, a umidade na base de massa ( $g$ de água/g de solo). Com o peso seco e o volume do cilindro amostrador, calculou-se a densidade aparente (Da) para cada amostra individualizada ( $\mathrm{g}$ de solo/ $\mathrm{cm} 3$ de solo). Com os dados de umidade, na base de massa (U), a densidade aparente e a altura do cilindro amostrador $(\mathrm{h}=3,3 \mathrm{~cm})$, calculou-se a lâmina de água pelo método gravimétrico (LG), utilizando a equação,

$$
\mathrm{LG}=(\mathrm{PSU}-\mathrm{PSS}) / \mathrm{PSS} \times \mathrm{Da} \times \mathbf{h}
$$

Os dados assim obtidos foram multiplicados por 10 para compatibilizar os resultados do método gravimétrico com os resultados determinados pelo HIDRO SAVER, já que a escala do instrumento é graduada em milímetros equivalentes (mm).

Por diferença das determinações do HIDRO SAVER (HSS e HSU), obtém-se a lâmina de água equivalente para aquele nível de umidade pela equação,

$$
\text { LHS }=\text { HSS }- \text { HSU }
$$

onde,

LHS lâmina de água equivalente ( $\mathrm{mm})$;

HSS lâmina de água determinada a partir do solo seco em estufa a $105^{\circ} \mathrm{C}(\mathrm{mm})$; HSU lâmina de água a partir do solo úmido (mm).

Os resultados de campo, obtidos pelos dois métodos, foram comparados, para avaliar se havia diferença significativa entre os resultados obtidos pelo método gravimétrico e pelo novo instrumento o HIDRO SAVER. 
3. 4. Testes dos métodos gravimétrico e do HIDRO SAVER para vários tipos de amostras.

\section{4. 1. Testes com corpos de prova.}

\section{4. 1. 1. Características dos corpos de prova e procedimento.}

Para aferir os resultados do HIDRO SAVER, afastando a possibilidade de interferência de outras variáveis tais como perda de material durante a manipulação, dilatação ou contração das amostras e variações na densidade, foram confeccionados cinco (05) corpos de prova com uma mistura de areia, silte e cimento, dentro de um cilindro amostrador de solo padrão do HIDRO SAVER $(3,3 \mathrm{~cm}$ de altura $\times 4,85 \mathrm{~cm}$ de $\emptyset$ interno, volume de $60.96 \mathrm{~cm}^{3}$ ) de modo a comportarem-se como solo, no que se refere à capacidade de retenção de água.

Os corpos de prova foram, inicialmente, colocados na estufa a $105^{\circ} \mathrm{C}$ por 24 horas. Daí, foram retirados e aguardou-se o seu resfriamento. Tomaram-se, então, os seus pesos secos (PSS) após o que, logo em seguida, foram levados ao HIDRO SAVER para a determinação da capacidade máxima de retenção de água da amostra (HSS). Após saírem do instrumento, o seu peso úmido (PSU) foi anotado para o cálculo da capacidade máxima de retenção de água da amostra (LG) pelo método gravimétrico. Com os valores do peso seco, e da altura do cilindro amostrador $(3,3 \mathrm{~cm})$, calcularam-se a densidade aparente ( $\mathrm{Da}$ ) para cada corpo de prova individualizado e para cada uma das repetições. A umidade na base de massa (U) transformada em lâmina de água pela equação (7), foi usada para fazer a comparação com os resultados determinados pelo novo instrumento, o HIDRO SAVER.

\section{4. 2. Testes com amostras de laboratório.}

3. 4. 2. Características das amostras e procedimento. 
Utilizou-se parte do material que está sendo estudado pelo Departamento de Solos da Universidade Federal Rural de Pernambuco - UFRPE, na atualização da classificação dos solos do Estado de Pernambuco, já que, nesse estudo determina-se, também pelos métodos clássicos da câmara de pressão, a capacidade de campo - CC (0.3 atm) e o ponto de murcha permanente - PMP - (15 atm).

$O$ procedimento adotado foi o seguinte: as amostras inicialmente saturadas, foram colocadas na câmara de pressão e submetidas às tensões de 0,3 e 15 atm, até que o equilibrio fosse estabelecido; quando as amostras saíram da câmara de pressão, foram tomados os pesos úmidos (PSU) e, depois, colocadas no HIDRO SAVER para a determinação da lâmina d'água complementar (HSU); e, em seguida, as mesmas amostras foram levadas à estufa $105^{\circ} \mathrm{C}$ por 48 horas; daí, foram tomados os pesos secos (PSS) e colocadas, novamente, no HIDRO SAVER para a determinação da capacidade máxima de armazenamento de água da amostra (HSS). Estes procedimentos foram executados para dois niveis de tensão 0,3 e $15 \mathrm{~atm}$. Com os pesos úmidos e secos, a densidade aparente e a altura das amostras (no caso, igual a $1,0 \mathrm{~cm}$ ), calcularam-se as lâminas de água das amostras pelo método gravimétrico (LG), transformando-se os resultados para mm pela equação (7).

Por diferença das determinações feitas pelo HIDRO SAVER (HSS HSU), obteve-se as lâminas de água equivalentes (LHS) para aqueles níveis de tensão.

\section{4. 3. Testes especiais com umidades aleatórias.}

\section{4. 3. 1. Características das amostras e procedimento.}

As amostras do primeiro experimento de campo foram aproveitadas para este teste. Os cilindros, com as amostras de campo foram trabalhados para corrigirem-se eventuais alterações no volume de solo. Depois, os cilindros foram colocados nas tampas das latas e uma certa quantidade de água foi colocada nas tampas, para que as amostras a absorvessem e perdessem água ao mesmo tempo. Assim, foram deixadas ao 
ar por três dias. Este esquema foi montado para que as amostras atingissem niveis de umidade aleatórios e o mais diversificados possíveis. Após três dias, foram tomados os pesos úmidos (PSU) das amostras e, em seguida, elas foram colocadas no HIDRO SAVER para determinar a lâmina de água complementar (HSU). Depois, as amostras foram levadas à estufa $105^{\circ} \mathrm{C}$, por 48 horas. Dai, tomou-se-lhes o peso seco (PSS) e, imediatamente, elas foram colocadas no HIDRO SAVER, para determinação da capacidade máxima de retenção de água das amostras (HSS). Com os valores do peso seco e da altura do cilindro amostrador $(3,3 \mathrm{~cm})$, calculou-se a densidade aparente (Da) para cada amostra individualizada. A umidade, na base de massa, transformada em lâmina de água pela equação (7), foi usada para fazer a comparação com os resultados determinados pelo novo instrumento, o HIDRO SAVER.

\section{4. 4. Teste da capacidade máxima de armazenamento de água das amostras.}

\section{4. 4. 1. Características das amostras e procedimento.}

Para este teste utilizaram-se as mesmas amostras coletadas para o segundo experimento de campo. Os cilindros, ainda com as amostras, foram trabalhados no sentido de corrigirem-se eventuais alterações de volume de solo. Depois, foram colocados em estufa a $105^{\circ} \mathrm{C}$, por 48 horas. Após este período, as amostras foram retiradas da estufa e determinado, inicialmente, o seu peso seco (PSS). Depois as amostras foram imediatamente colocadas no HIDRO SAVER, para a determinação da capacidade máxima de retenção de água da amostra (HSS). Daí, foram tomados os pesos úmidos (PSU). Com os valores do peso seco e da altura do cilindro amostrador $(3,3 \mathrm{~cm})$ calculou-se a densidade aparente (Da), para cada amostra individualizada. A umidade, na base de massa, assim calculada, corresponde à capacidade máxima de armazenamento de água da amostra, determinada gravimetricamente (LG). Os valores de umidade, na base de massa (U), foram transformados em lâmina de água pela 
equação (7) e usados para fazer a comparação com os resultados determinados pelo novo instrumento, o HIDRO SAVER. 


\section{RESULTADOS E DISCUSSÕES}

\section{1 Desempenho do HIDRO SAVER.}

\section{1. 1 Condições operacionais.}

Evidenciou-se a redução de erros nas determinações por tratar-se de um instrumento de leitura direta que dispensa, conseqüentemente, correções, ajustes, interpretação de resultados ou a utilização de acessórios auxiliares. Como todo equipamento de leitura direta é possível haver erros devido às paralaxes.

O HIDRO SAVER apresentou, ainda, simplicidade operacional por requerer apenas reabastecimento da torre (reservatório de água), colocação de amostra na mesa de recepção e leitura do resultado. Além disso, pode-se utilizar toda a altura da escala na torre para várias determinações sem necessidade de reabastecimento. A diferença entre as leituras final e inicial corresponde à lâmina de água complementar (LC) da amostra do solo.

O nível da água na célula de distribuição é estável, o que proporciona ao instrumento precisão nas determinações, além de sensibilidade.

A esponja colocada no interior da célula de distribuição é eficiente para promover o contato com a amostra de solo, e manter a continuidade da coluna de água da torre até à base da amostra do solo.

$O$ equipamento apresenta precisão instrumental de até $0,05 \mathrm{~mm}$, satisfatória para o fim a que se destina (determinar a lâmina complementar e a capacidade máxima de armazenamento de água da amostra do solo), já que, embora se possa atingir níveis de precisão de até $0,02 \mathrm{~mm}$, com o emprego de micrômetro de 
gancho, em tanque "classe A", na determinação da lâmina complementar a ser aplicada na irrigação, o erro nos métodos, quando de sua aplicação, será sempre superior nos diferentes sistemas de irrigação existentes.

Os resultados obtidos pelo HIDRO SAVER, quando comparados aos demais métodos utilizados mostraram não haver diferença significativa em nível de $10 \%$ de probabilidade, pelo teste de Tukey, ou seja, que os dados obtidos pelo HIDRO SAVER e pelo método gravimétrico, este tomado como padrão, não apresentam diferenças estatisticamente significativas.

Durante toda a fase experimental não se evidenciou necessidade de manutenção do HIDRO SAVER, resumindo-se apenas à sua limpeza com água corrente.

Os tempos de 30 segundos para amostras de $1 \mathrm{~cm}$ de altura e de 60 segundos para amostras de $3,3 \mathrm{~cm}$ de altura, como limites de frequência de bolha adotados neste trabalho (liberação de cotas de água, da torre para a amostra, pelo HIDRO SAVER) podem ser considerados como indicados para a leitura final do instrumento, tendo em vista os resultados nele obtidos. Tempos maiores que 60 segundos podem afetar os resultados devido à demanda atmosférica, com perda de água pela parte superior da amostra, mesmo com a utilização do disco limitador de evaporação para proteção da amostra.

$\mathrm{Na}$ determinação da lâmina equivalente de água, o HIDRO SAVER levou, em média, 5 minutos para o resultado final. Nos outros métodos empregados, este mesmo resultado só é obtido com aproximadamente, 280 vezes mais tempo.

\section{1. 2. Resultados relativos aos corpos de prova.}

Os testes com os corpos de prova foram elaborados para servirem como referência e controle para os outros testes. Para isso, procurou-se exercer o maior controle possível no processo, objetivando reduzir algumas fontes de variações, como a perda de material, adensamento, contração, dilatação, e outras variações na estrutura e distribuição dos poros das amostras. Os resultados obtidos nestes testes, revelaram que os efeitos dessas fontes de variações foram minimizadas. Ficou evidenciado, pelos 
resultados obtidos no método da câmara de pressão, que essas fontes de variação podem interferir significativamente nos resultados.

A tabela 1 apresenta as médias dos resultados obtidos com os cinco corpos de prova. $\mathrm{O}$ coeficiente de correlação $\mathrm{R}=0,9998$ mostra a estreita relação dos resultados obtidos pelo HIDRO SAVER, quando comparado ao método gravimétrico, que foi tomado como padrão. As diferenças relativas, Dr $<-0,54 \%$, mostram-se, numericamente, bastante pequenas, embora o processo para obtenção dos resultados seja exatamente inverso (no HIDRO SAVER o processo é por molhamento, enquanto que, no método gravimétrico, é por secamentos). Os dados obtidos pelos dois métodos não apresentam diferença estatisticamente significativa, em nivel de $10 \%$ de probabilidade, pelo teste de Tukey.

Tabela 1 -Resultados dos testes de laboratório, determinação da capacidade máxima de retenção de água pelo método gravimétrico (LG) e pelo HIDRO SAVER (LHS) utilizando corpo de provas.

\begin{tabular}{|c|c|c|c|c|c|c|c|c|c|c|c|c|}
\hline $\begin{array}{l}\mathbf{C P} \\
n^{\circ}\end{array}$ & $\begin{array}{c}\text { PSU } \\
\mathbf{g}\end{array}$ & $\begin{array}{c}\text { PSS } \\
\text { g }\end{array}$ & $\begin{array}{c}\text { Ph20 } \\
\text { g }\end{array}$ & $\begin{array}{c}U \\
g \cdot g^{-1}\end{array}$ & $\begin{array}{c}\overline{\mathrm{Da}} \\
\mathrm{g.cm}{ }^{-3}\end{array}$ & $\begin{array}{c}\mathrm{q} \\
\mathrm{cm}^{3} \cdot \mathrm{cm}^{-3}\end{array}$ & $\begin{array}{l}\mathrm{H} \\
\mathrm{cm}\end{array}$ & $\begin{array}{l}\mathrm{L} \\
\mathrm{cm}\end{array}$ & $\begin{array}{c}\text { LG } \\
\mathbf{m m}\end{array}$ & $\begin{array}{l}\text { LHS } \\
\mathbf{m m}\end{array}$ & $\begin{array}{l}\text { Dr } \\
\%\end{array}$ & $\begin{array}{c}\text { Teste } \\
\mathrm{T}\end{array}$ \\
\hline 1 & 96,16 & 67,04 & 29,11 & 0,43424 & 1,12 & 0,48546 & 3,3 & 1,602 & 16,02 & 16,08 & $-0,37$ & NS \\
\hline 2 & 92,70 & 63,95 & 28,75 & 0,44954 & 1,06 & 0,47848 & 3,3 & 1,579 & 15,79 & 15,73 & 0,38 & NS \\
\hline 3 & 102,44 & 78,84 & 23,60 & 0,29938 & 1,31 & 0,39285 & 3,3 & 1,296 & 12,96 & 12,96 & -0 & NS \\
\hline 4 & 106,45 & 83,19 & 23,26 & 0,27962 & 1,39 & 0,38726 & 3,3 & 1,278 & 12,78 & 12,71 & 0,54 & NS \\
\hline 5 & 149,00 & 114,08 & 34,93 & 0,30617 & 1,26 & 0,38678 & 5,0 & 1,934 & 19,34 & 19,29 & 0,26 & NS \\
\hline
\end{tabular}

Correl - 0,9998

(1) - Valores médios dos resultados com corpos de provas.

LG - Lâmina d'água calculada pelo método gravimétrico.

LHS - Lâmina d’água determinada pelo HIDRO SAVER.

Dr - Diferença relativa entre os dados obtidos pelos dois métodos.

CP - Corpo de provas.

NS - As médias ñ̃o apresentam diferenças significativas pelo teste de Tukey em nivel de $10 \%$ de probabilidade.

A figura 7 mostra as linhas de tendência do tipo regressão linear, a partir dos dados obtidos pelos dois métodos. $\mathrm{O}$ paralelismo das linhas de tendência mostram a similaridade dos resultados obtidos pelos dois métodos testados, o que credencia o novo instrumento proposto como capaz de reproduzir resultados estatisticamente iguais aos do método considerado como padrão. 


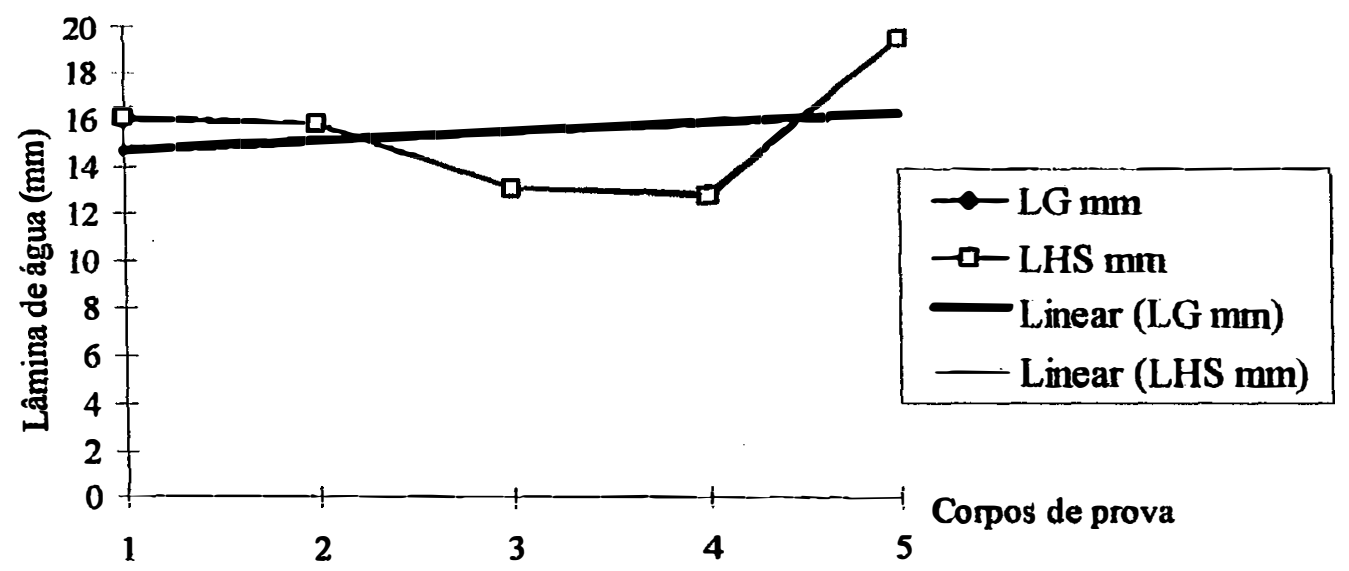

Figura 7 - Resultados dos testes com corpos de provas, média por elemento

\section{1. 3 Resultados relativos aos testes de laboratório.}

4. 1. 3. 1. Com amostras desestruturadas submetidas à câmara de pressão.

Os testes com amostras desestruturadas foram realizados com o objetivo de compararem-se os valores de capacidade de campo (CC 0,3 atm) e de ponto de murcha permanente (PMP 15,0 atm) calculados pelo método da câmara de pressão com os valores determinadas pelo HIDRO SAVER.

A tabela 2 e as figuras 8 e 9 mostram os valores médios, por perfil e para cada nível de tensão. Os primeiros três perfís, 5 a 7, mostram variações acentuadas nos níveis de correlação e apresentam resultados estatísticos que indicam diferenças significativas entre os valores calculados pelo método da câmara de pressão e os dados determinados pelo HIDRO SAVER.

As diferenças evidenciadas nos primeiros perfis, 5, 6 e 7, podem ser explicados pelas dificuldades iniciais de retirada das amostras da placa porosa da câmara de pressão, uma vez que estavam acondicionadas em anéis de borracha com 
Tabela 2 - Resultados dos testes de laboratório com amostras desestruturadas. Comparação das lâminas de água calculadas pelo método da câmara de pressão com os valores determinados pelo Hidro Saver.

\begin{tabular}{|c|c|c|c|c|c|c|c|c|c|c|c|c|}
\hline \multicolumn{7}{|c|}{ Capacidade de campo 0,3 atm } & \multicolumn{6}{|c|}{ Ponto de Murcha permanente $15,0 \mathrm{~atm}$. } \\
\hline Perfil & $\begin{array}{l}\mathbf{L C P} \\
\mathrm{mm}\end{array}$ & $\begin{array}{l}\text { HSU } \\
\text { mm }\end{array}$ & $\begin{array}{l}\text { HSS } \\
\mathrm{mm}\end{array}$ & $\begin{array}{l}\text { LHS } \\
\text { mm }\end{array}$ & $\begin{array}{l}\text { Dr } \\
\%\end{array}$ & $\begin{array}{c}\text { Correl } \\
\mathbf{R}\end{array}$ & $\begin{array}{c}\mathbf{L C P} \\
\mathrm{mm}\end{array}$ & $\begin{array}{l}\text { HSU } \\
\mathrm{mm}\end{array}$ & $\begin{array}{l}\text { HSS } \\
\mathrm{mm}\end{array}$ & $\begin{array}{l}\text { LHS } \\
\mathrm{mm}\end{array}$ & $\begin{array}{l}\mathrm{Dr} \\
\%\end{array}$ & $\begin{array}{c}\text { Correl } \\
\mathbf{R}\end{array}$ \\
\hline 5 & 3,11 & 2,90 & 5,77 & 2,87 & $\overline{7,72}$ & 0,9844 NS & 3,10 & 4,01 & 6,19 & 2,18 & 29,68 & $0,9909 \mathrm{~S}$ \\
\hline 6 & 3,06 & 2,91 & 6,33 & 3,43 & $-12,09$ & 0,7119 NS & 2,24 & 3,00 & 6,30 & 3,30 & $-47,32$ & $0,19087 \mathrm{~S}$ \\
\hline 7 & 6,08 & 2,59 & 7,49 & 4,91 & 19,24 & ני טאוס 0,0 & 4,20 & 3,10 & 7,85 & 4,76 & $-13,33$ & $0,8607 \mathrm{NS}$ \\
\hline 8 & 3,73 & 2,17 & 6,12 & 3,95 & $-5,90$ & 0,7974 NS & 2,24 & 3,74 & 6,41 & 2,67 & $-19,20$ & 0,9734 NS \\
\hline 9 & 2,80 & 2,75 & 5,49 & 2,74 & 2,14 & $0,9889 \mathrm{NS}$ & 1,68 & 3,36 & 5,40 & 2,04 & $-21,43$ & $0,9230 \mathrm{NS}$ \\
\hline 10 & 2,01 & 2,87 & 5,42 & 2,55 & $-26,86$ & $0,9585 \mathrm{NS}$ & 1,35 & 3,20 & 5,49 & 2,29 & $-69,63$ & $0,9249 \mathrm{NS}$ \\
\hline
\end{tabular}

(1) -Valores médios dos perfis.

LCP - Lâmina de água calculada pelo método da Câmara de Pressão.

LHS - Lâmina de água determinada pelo HIDRO SAVER

HSU - Lâmina de água a partir da amostra úmida a $0,3 \mathrm{~atm}$ ou a $15,0 \mathrm{~atm}$.

HSS - Lâmina de água a partir da amostra seca em estufa à $105^{\circ} \mathrm{C}$

Dr - Diferença relativa entre os dados obtidos pelos dois métodos

NS - As médias não apresentam diferenças significativas pelo teste de Tukey em nível de $10 \%$ de probabilidade.

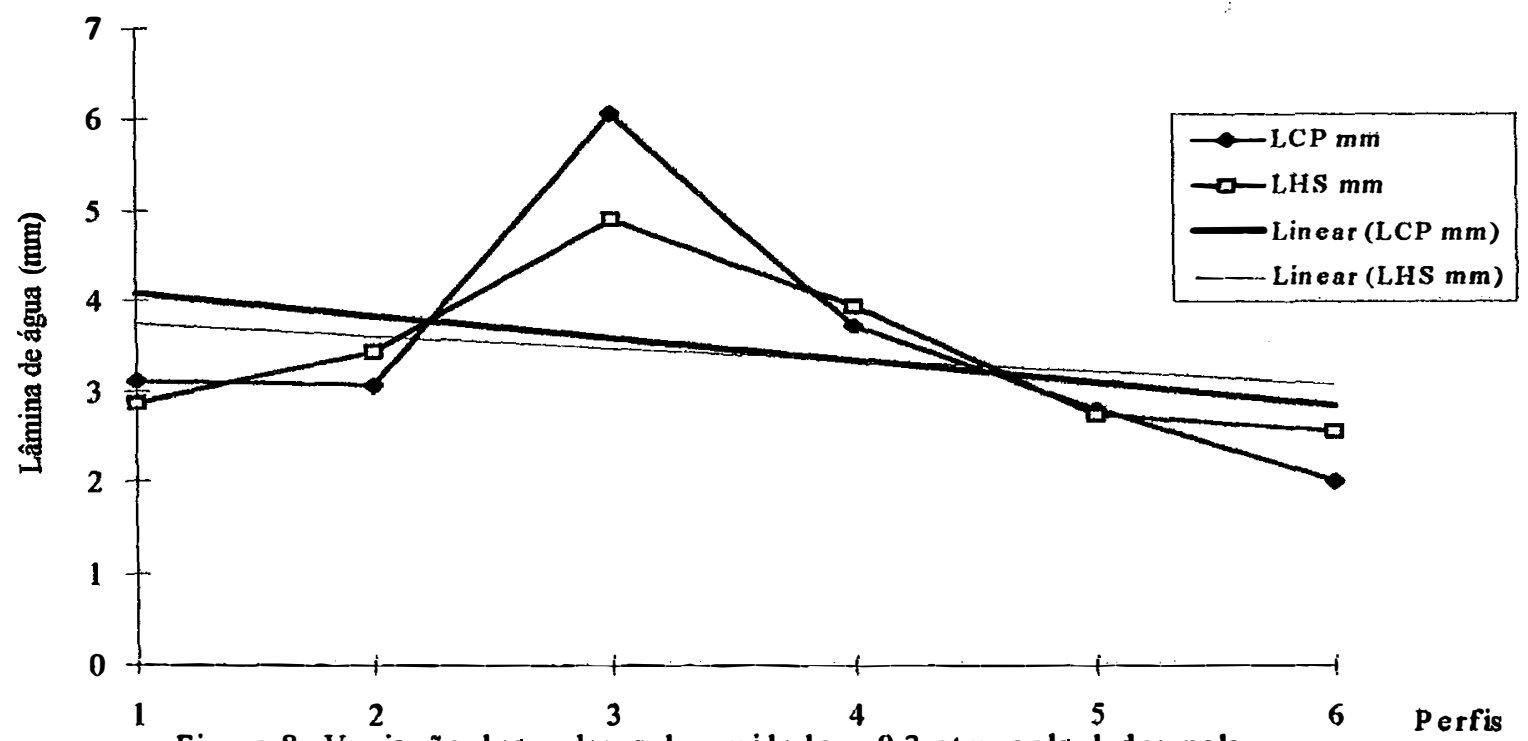

Figura 8 -Variação dos valores de umidade a $0,3 \mathrm{~atm}$, calculados pelo método da câmara de pressão e pelo HIDRO SA VER. 


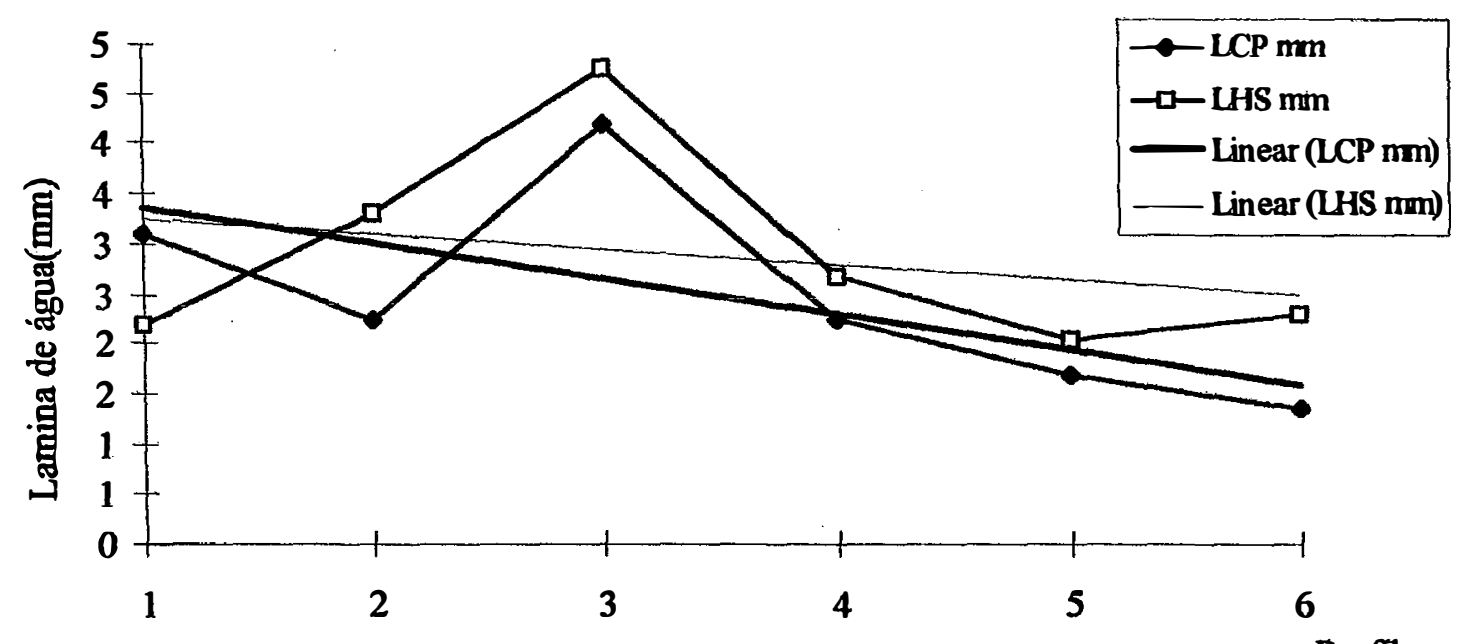

Figura 9 - Variação dos valores de umidade a $15,0 \mathrm{~atm}$, calculados pelo

Perfil método da câmara de pressão e pelo HIDRO SAVER.

diâmetro maior do que o do anel padrão do HIDRO SAVER. As amostras tinham que ser quebradas e colocadas no anel do HIDRO SAVER. Esta prática, certamente, vinha a alterar a geometria dos poros e a densidade aparente da amostra sobre a qual a umidade estaria sendo determinada na câmara de pressão. Esta dificuldade foi solucionada a partir do perfil 8.

A solução encontrada foi substituir os anéis de borracha por anéis de alumínio com diâmetro padrão para o HIDRO SAVER. Depois que esta modificação foi adotada, os resultados mostraram-se mais consistentes.

As diferenças numéricas observadas podem ser atribuídas ao fato de que, no método da câmara de pressão, a umidade é calculada com amostras desestruturadas. Entretanto, em seguida, utilizou-se a densidade aparente calculada em amostras estruturadas, pelo método do torrão, para expressar a umidade em lâmina de água. Enquanto que, no HIDRO SAVER, as lâminas de água são determinadas diretamente, com as amostras nas condições que saíam da placa. Portanto, os resultados do HIDRO SAVER refletem diretamente a lâmina d'água das amostras, naquelas condições, já que não há necessidade de nenhuma outra determinação ou cálculos auxiliares, conforme 
demonstraram os resultados. A rigor, nos testes, as lâminas de água foram determinadas em amostras com características físicas distintas das amostras dos solos estudados. Os dados finais indicam que este procedimento pode alterar significativamente os resultados.

A troca dos anéis de borracha por anéis de alumínio reduziu as fontes de variações. Com os anéis de alumínio, a retirada das amostras das placas ficou mais rápida e fácil. Após a pesagem, as amostras podiam ser colocadas diretamente no HIDRO SAVER sem alterar o seu acondicionamento nos anéis.

A análise estatística dos resultados observados a partir do perfil 8, depois da substituição dos anéis, indicam que os valores de lâmina de água determinadas pelo HIDRO SAVER, quando comparados com os das lâminas de água calculadas pelo método da câmara de pressão, não diferem estatisticamente, em nívelde 5\% de probabilidade, pelo teste Tukey. Podem-se atribuir estes resultados a uma menor manipulação das amostras após saírem da câmara de pressão. Os coeficientes de correlação $\mathrm{R}>0,900$ comprovam a relação dos resultados obtidos pelos dois métodos. Entretanto, as diferenças relativas $\mathrm{Dr}<69 \%$ são elevadas e apontam para diferenças numéricas consideráveis entre os resultados dos métodos testados, embora, estatisticamente, não se diferenciem dos resultados médios.

Entretanto, a consistência dos dados obtidos pelo HIDRO SAVER pode ser comprovada pelos resultados das análises estatísticas que mostram não haver diferença significativa, em nível de $5 \%$ de probabilidade, quando comparados os dados da HSS a $0,3 \mathrm{~atm}$ com a HSS a 15,0 atm, tabela 3 . A HSS corresponde à capacidade máxima de armazenamento de água da amostra, expressa em lâmina de água. Este resultado vem confirmar a reprodutibilidade dos dados obtidos pelo novo instrumento mesmo em condições pouco indicadas para seu uso, considerando-se que o instrumento foi concebido para ser utilizado com o solo em condições naturais.

A observação acima toma-se mais evidente quando analisada à luz dos resultados observados no teste com corpos de prova. Quando, as fontes de erros tais como perda de material, contração, dilatação, alterações na porosidade e na densidade das amostras etc... foram minimizadas, além dos resultados estatísticos indicarem a 
similaridade dos dados, os próprios valores numéricos das lâminas de água apresentaram variações tão pequenas que estão abaixo da própria escala do instrumento $(0,1 \mathrm{~mm})$.

Tabela 3 - Resultados dos testes de laboratório, medidas da capacidade máxima de armazenamento de água das amostras secas em estufa a $105^{\circ} \mathrm{C}$ determinadas pelo HIDRO SAVER..

\begin{tabular}{|c|c|c|c|c|}
\hline Perfil & HSS $0,3 \mathrm{~atm}$ & HSS $15,0 \mathrm{~atm}$ & Dr & Teste \\
\hline $\mathrm{N}$ & $(\mathrm{mm})$ & $(\mathrm{mm})$ & $(\%)$ & $\mathrm{T}$ \\
\hline 5 & 5,77 & 6,19 & $-7,28$ & NS \\
\hline 6 & 6,33 & 6,30 & 0,47 & NS \\
\hline 7 & 7,49 & 7,85 & $-4,81$ & NS \\
\hline 8 & 6,12 & 6,41 & $-4,74$ & NS \\
\hline 9 & 3,67 & 3,82 & $-4,09$ & NS \\
\hline 10 & 5,88 & 6,11 & $-3,91$ & NS \\
\hline
\end{tabular}

Correl $-0,9930$

(1) - Valores médios por perfl.

HSS - Lâmina de água a partir do solo seco em estufa a $105^{\circ} \mathrm{C}$.

Dr - Diferença relativa entre os dados.

T - Teste de Tukey ao nivel de $10 \%$ de probabilidade.

NS - As médias não apresentam diferenças significativas.

$S$ - As médias diferem significativamente.

\section{1. 3. 2 Testes com umidades aleatórias em amostras com} estrutura indeformada.

Nos testes com umidades aleatórias, foram utilizadas as amostras com estruturas indeformadas do primeiro experimento de campo, perfil I, coletadas em cilindros amostradores, padrão do HIDRO SAVER. Este teste objetivou a aferição dos resultados obtidos pelo HIDRO SAVER em relação aos dados calculados pelo método gravimétrico, nos mais variados níveis de umidade possíveis.

A análise estatística dos resultados mostram que os dados obtidos pelos dois métodos não diferem estatisticamente em nível de $5 \%$ de probabilidade, pelo teste Tukey. 
A tabela 4 apresenta as médias dos resultados obtidos pelos dois métodos. $O$ coeficiente de correlação $R>0,9997$ mostra a estreita correlação dos dados obtidos pelos dois métodos. As diferenças relativas $\mathrm{Dr}<-0,41 \%$ evidenciam que os valores numéricos obtidos pelos métodos testados não apresentam diferenças expressivas.

Tabela 4 - Teste de laboratório com umidades aleatória, comparação das lâminas de água calculadas pelo método gravimétrico (LG) com as lâminas de água determinadas pelo HIDRO SAVER (LHS), utilizando amostras indeformadas do perfil 1 .

\begin{tabular}{|c|c|c|c|c|c|c|c|c|c|c|c|c|}
\hline $\begin{array}{c}\text { Repet. } \\
\text { n }\end{array}$ & $\begin{array}{c}\mathbf{P U} \\
\mathrm{g}\end{array}$ & $\begin{array}{c}\overline{\text { PS }} \\
\mathrm{g}\end{array}$ & $\begin{array}{c}U \\
g \cdot g^{-1}\end{array}$ & $\begin{array}{c}\mathrm{da} \\
\mathrm{g.cm}^{-3}\end{array}$ & $\begin{array}{c}\theta \\
\mathrm{cm}^{3} \cdot \mathrm{cm}^{-3}\end{array}$ & $\begin{array}{c}\mathrm{H} \\
\mathrm{cm}\end{array}$ & $\begin{array}{l}\mathrm{LG} \\
\mathrm{cm}\end{array}$ & $\begin{array}{l}\mathbf{L G} \\
\mathbf{m m}\end{array}$ & $\begin{array}{l}\text { HSU } \\
\mathbf{m m}\end{array}$ & $\begin{array}{l}\text { HSS } \\
\mathrm{mm}\end{array}$ & $\begin{array}{c}\text { LHS } \\
\mathrm{mm}\end{array}$ & $\begin{array}{l}\mathrm{Dr} \\
\%\end{array}$ \\
\hline 1 & 101,58 & 87,12 & 0,16603 & 1,43 & 0,23726 & 3,30 & 0,7830 & $\overline{7,83}$ & 2,11 & 10,03 & 7,92 & $-1,15$ \\
\hline 2 & 102,17 & 90,46 & 0,12983 & 1,48 & 0,19198 & 3,30 & 0,6335 & 6,34 & 3,15 & 9,62 & 6,48 & $-2,21$ \\
\hline 3 & 106,25 & 102,36 & 0,03790 & 1,68 & 0,06387 & 3,30 & 0,2108 & 2,11 & 6,29 & 8,33 & 2,04 & 3,32 \\
\hline 4 & 105,50 & 103,06 & 0,02368 & 1,69 & 0,04003 & 3,30 & 0,1321 & 1,32 & 6,36 & 7,70 & 1,33 & $-0,76$ \\
\hline 5 & 101,61 & 97,70 & 0,04002 & 1,60 & 0,06403 & 3,30 & 0,2113 & 2,11 & 6,81 & 8,88 & 2,07 & 1,90 \\
\hline 6 & 104,64 & 100,33 & 0,04297 & 1,65 & 0,07076 & 3,30 & 0,2335 & 2,33 & 5,77 & 8,10 & 2,33 & -0 \\
\hline 7 & 104,19 & 101,25 & 0,02918 & 1,66 & 0,04823 & 3,30 & 0,1592 & 1,59 & 6,66 & 8,25 & 1,59 & -0 \\
\hline 8 & 99,63 & 96,90 & 0,02812 & 1,59 & 0,0 & 3,30 & 0,1478 & 1,48 & 7,55 & 9,07 & 1,52 & $-2,70$ \\
\hline 9 & 104,99 & 99,61 & 0,05406 & 1,63 & 0,08831 & 3,30 & 0,2914 & 2,91 & 5,40 & 8,44 & 3,03 & $-4,12$ \\
\hline 10 & 104,29 & 98,85 & 0,05513 & 1,62 & 0,08935 & 3,30 & 0,2948 & 2,10 & 3,52 & 5,70 & 2,18 & $-3,81$ \\
\hline 11. & 107,24 & 99,35 & 0,07936 & 1,63 & 0,12943 & 3,30 & 0,4271 & 4,27 & 4,85 & 9,21 & 4,37 & $-2,34$ \\
\hline 12 & 107,24 & 99,85 & 0,07410 & 1,64 & 0,12123 & 3,30 & 0,4000 & 4,00 & 4,92 & 8,95 & 4,03 & $-0,75$ \\
\hline 13 & 98,24 & 97,17 & 0,01108 & 1,59 & 0,01761 & 3,30 & 0,0581 & 0,38 & 5,77 & 6,14 & 0,37 & 2,63 \\
\hline 14 & 98,84 & 97,80 & 0,01067 & 1,60 & 0,01712 & 3,30 & 0,0565 & 0,39 & 6,03 & 6,40 & 0,37 & 2,13 \\
\hline
\end{tabular}

Correl - 0,9998

Volume do cilindro $-60,96 \mathrm{~cm}^{3}$

(1) - Valores médios dos resultados com corpos de provas.

LG - Lâmina de água calculada pelo método gravimétrico.

LHS -Lâmina de água determinada pelo HIDRO SAVER.

HSU - Lâmina de água determinada pelo HIDRO SAVER a partir do solo úmido.

HSS - Lâmina de água deteminada pelo HIDRO SAVER a partir do solo seco em estufa.

Dr - Diferença relativa entre os dados obtidos pelos dois métodos.

Os resultados deste teste podem ser visualizados na figura 10 , onde as linhas de tendência, tipo regressão linear, mostram a similaridade dos dados obtidos pelos dois métodos ao longo das repetições. 


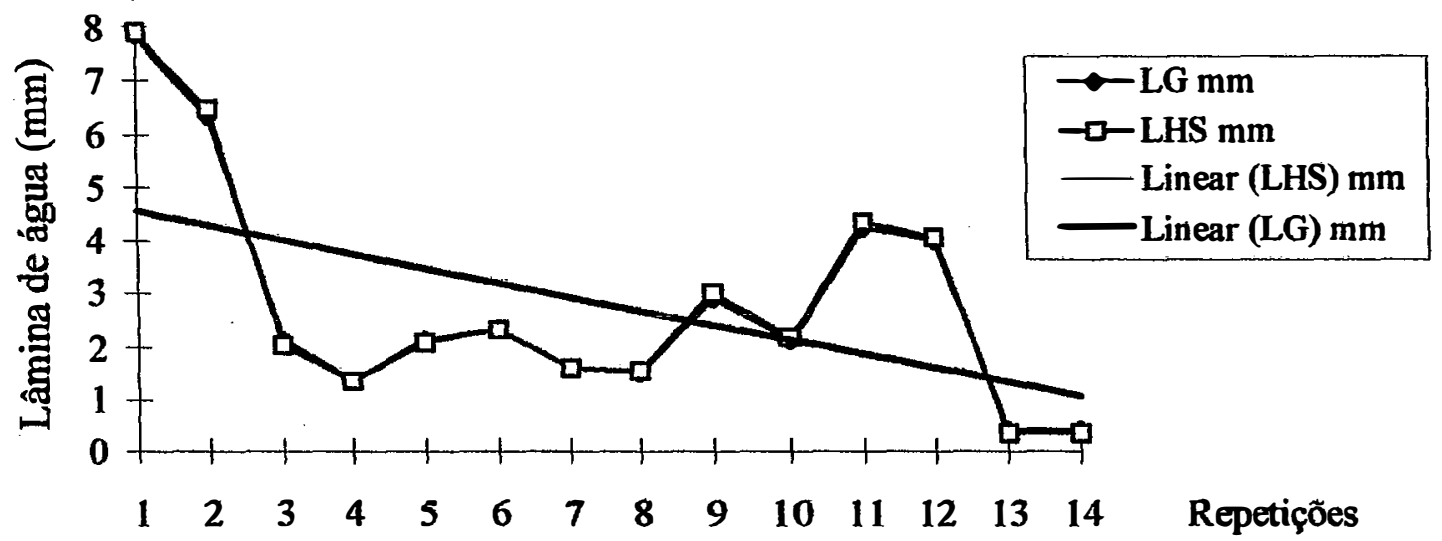

Figura 10 - Variação dos dados de umidade aleatória em amostra com estrutura indeformadas, média de três repetições.

\section{1. 3. 3. Testes da capacidade máxima de retenção de água} em amostras indeformadas.

Nestes testes buscou-se avaliar o desempenho do HIDRO SAVER para a determinação da capacidade máxima de retenção de água em amostras com estrutura indeformada, em relação aos mesmos dados calculados pelo método gravimétrico.

Os resultados (tabela 5) mostram que os dados obtidos pelo HIDRO SAVER, não diferem dos dados calculados pelo método gravimétrico em nível de $5 \%$ de probabilidade, pelo teste Tukey. A análise estatística revelou um coeficiente de correlação $\mathrm{R}>0,987$ e diferença relativa $\mathrm{Dr}=-2,78$, em média. Estes valores evidenciam a equivalência dos resultados obtidos pelos dois métodos. As diferenças relativas mais acentuadas podem ser atribuídas às perdas de material quando da retirada do cilindro do HIDRO SAVER para obtenção do peso úmido, além do fenômeno da histerese.

A figura 11 mostra as linhas de tendência do tipo regressão linear, evidenciando o comportamento dos dados ao longo das repetições. 
Tabela 5 - Teste de laboratório na capacidade máxima de armazenamento de água das amostras, comparação das lâminas de água, calculadas pelo método gravimétrico (LG) com as lâminas de água determinadas pelo HIDRO SAVER (LHS), utilizando amostras indeformadas do perfil II.

\begin{tabular}{|c|c|c|c|c|c|c|c|c|c|c|}
\hline $\begin{array}{c}\text { Prof. } \\
\text { cm }\end{array}$ & $\begin{array}{c}\mathrm{PU} \\
\mathrm{g}\end{array}$ & $\begin{array}{c}\text { PS } \\
\text { g }\end{array}$ & $\begin{array}{c}\mathrm{U} \\
\mathrm{g} \cdot \mathrm{g}^{-1}\end{array}$ & $\begin{array}{c}\mathrm{Da} \\
\mathrm{g} \mathrm{cm}^{-3}\end{array}$ & $\begin{array}{c}\theta \\
\mathrm{cm}^{3} \cdot \mathrm{cm}^{-3}\end{array}$ & $\begin{array}{l}\mathrm{H} \\
\mathrm{cm}\end{array}$ & $\begin{array}{l}\mathrm{LG} \\
\mathrm{cm}\end{array}$ & $\begin{array}{l}\mathbf{L G} \\
\mathbf{m m}\end{array}$ & $\begin{array}{l}\text { HSS } \\
\text { mm }\end{array}$ & $\begin{array}{l}\mathrm{Dr} \\
\%\end{array}$ \\
\hline 1 & 100,70 & 85,35 & 0,17985 & 1,40 & 0,25180 & 3,30 & 0,8310 & $\overline{\mathbf{8 , 3 1}}$ & 8,77 & $-5,53$ \\
\hline 2 & 102,79 & 84,56 & 0,21558 & 1,39 & 0,29899 & 3,30 & 0,9867 & 9,87 & 9,84 & 0,30 \\
\hline 3 & 101,29 & 84,49 & 0,19904 & 1,39 & 0,27559 & 3,30 & 0,9094 & 9,09 & 9,32 & $-2,53$ \\
\hline 4 & 113,54 & 100,46 & 0,13020 & 1,65 & 0,21457 & 3,30 & 0,7081 & 7,08 & 7,16 & $-1,13$ \\
\hline 5 & 117,71 & 103,60 & 0,13622 & 1,70 & 0,23141 & 3,30 & 0,7636 & 7,64 & 7,77 & $-1,70$ \\
\hline 6 & 115,10 & 101,67 & 0,13221 & 1,67 & 0,22025 & 3,30 & 0,7268 & 7,27 & 7,47 & $-2,75$ \\
\hline 7 & 114,83 & 100,68 & 0,14065 & 1,65 & 0,23223 & 3,30 & 0,7664 & 7,66 & 7,88 & $-2,87$ \\
\hline 8 & 115,37 & 100,68 & 0,14724 & 1,65 & 0,24109 & 3,30 & 0,7956 & 7,96 & 8,21 & $-3,14$ \\
\hline 9 & 116,07 & 101,30 & 0,14583 & 1,66 & 0,24229 & 3,30 & 0,7996 & 8,00 & 8,14 & $-1,75$ \\
\hline 10 & 120,80 & 105,80 & 0,14177 & 1,74 & 0,24606 & 3,30 & 0,8120 & 8,12 & 8,36 & $-2,96$ \\
\hline 11 & 117,17 & 101,89 & 0,14995 & 1,67 & 0,25060 & 3,30 & 0,8270 & 8,27 & 8,47 & $-2,42$ \\
\hline 12 & 115,27 & 100,14 & 0,15106 & 1,64 & 0,24814 & 3,30 & 0,8189 & 8,19 & 8,47 & $-3,42$ \\
\hline 13 & 112,49 & 95,69 & 0,17557 & 1,57 & 0,27559 & 3,30 & 0,9094 & 9,09 & 9,27 & $-1,98$ \\
\hline 14 & 122,85 & 107,96 & 0,13795 & 1,77 & 0,24426 & 3,30 & 0,8061 & 8,06 & 8,27 & $-2,60$ \\
\hline 15 & 118,24 & 104,24 & 0,13431 & 1,71 & 0,22966 & 3,30 & 0,7579 & 7,58 & 7,99 & $-5,41$ \\
\hline 16 & 112,26 & 96,91 & 0,15839 & 1,59 & 0,25180 & 3,30 & 0,8310 & 8,31 & 8,40 & $-1,08$ \\
\hline 17 & 117,41 & 102,75 & 0,14266 & 1,69 & 0,24043 & 3,30 & 0,7934 & 7,93 & 8,36 & $-5,42$ \\
\hline 18 & 122,13 & 109,04 & 0,12004 & 1,79 & 0,21473 & 3,30 & 0,7086 & 7,09 & 7,29 & $-2,82$ \\
\hline 19 & 112,75 & 96,78 & 0,16512 & 1,59 & 0,26208 & 3,30 & 0,8649 & 8,65 & 8,88 & $-2,66$ \\
\hline 20 & 113,50 & 96,89 & 0,17175 & 1,59 & 0,27236 & 3,30 & 0,8988 & 8,99 & 9,29 & $-3,34$ \\
\hline 21 & 113,62 & 97,85 & 0,16139 & 1,61 & 0,25875 & 3,30 & 0,8539 & 8,54 & $\mathbf{8 , 8 8}$ & $-3,98$ \\
\hline 22 & 113,44 & 96,93 & 0,17048 & 1,59 & 0,27078 & 3,30 & 0,8936 & 8,94 & 9,10 & $-1,79$ \\
\hline 23 & 112,80 & 96,09 & 0,17399 & 1,58 & 0,27420 & 3,30 & 0,9048 & 9,05 & 9,27 & $-2,43$ \\
\hline
\end{tabular}

Correl - 0,9873

Volume do cilindro $=60,96 \mathrm{~cm}^{3}$

(1) - Valores médios de três repetiçōes.

LG - Lâmina de água calculada pelo método gravimétrico.

LHS - Lâmina de água determinada pelo HIDRO SAVER.

HSU - Lâmina de água determinada pelo HIDRO SAVER a partir do solo úmido.

HSS - Lâmina de água determinada pelo HIDRO SAVER a partir do solo seco em estufa.

Dr- Diferença relativa entre os dados obtidos pelos dois métodos. 


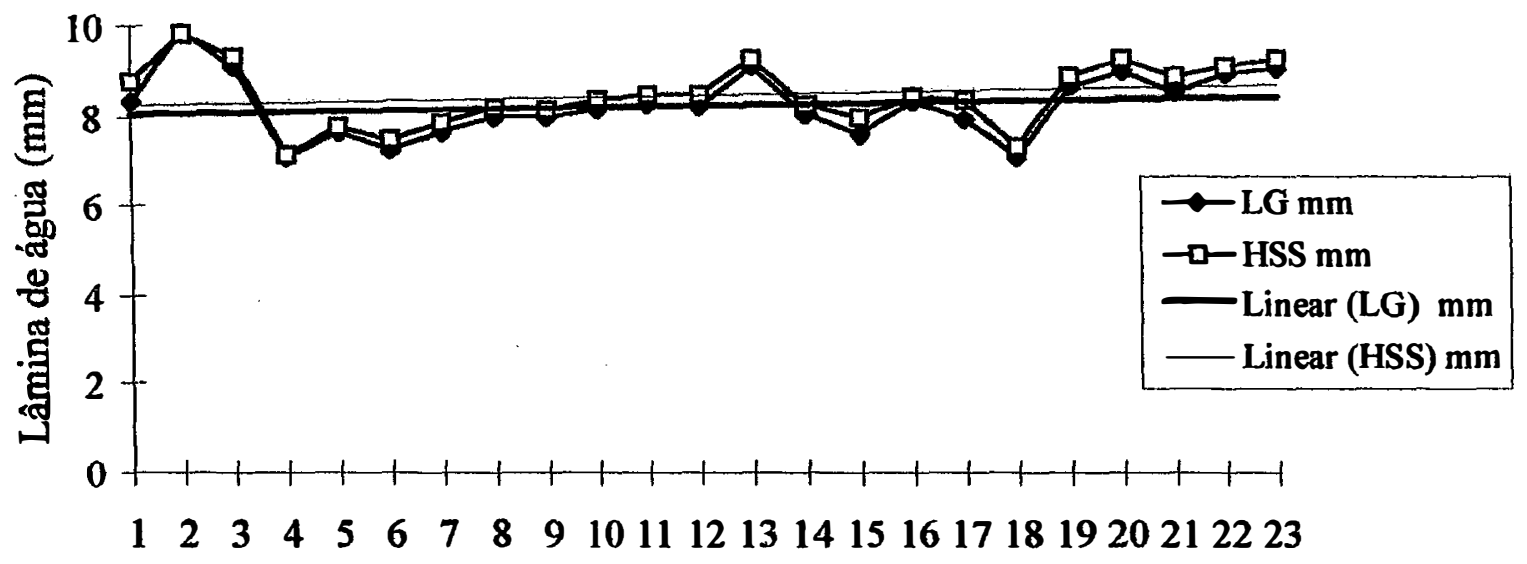

Figura 11- Testes da capacidade máxima de retenção de água das amostras, média de três repetições.

\section{1. 4. Resultados relativos aos experimentos de campo:}

Os valores relativos às propriedades químicas e físicas dos solos utilizados no experimento de campo, podem ser visualizados no apêndice.

Os resultados dos experimentos de campo nos perfís I e II estão resumidos nas tabelas 6 e 7 .

A análise estatística dos dados mostra que as determinações das lâminas de água, obtidas pelo novo instrumento não diferem dos mesmos dados calculados pelo método gravimétrico, em nível de $5 \%$ de probabilidade pelo teste de Tukey.

Os dados apresentam um coeficiente de correlação $R>0,998$ para 0 perfil I e $\mathrm{R}>0,997$ para o perfil II. As diferenças relativas (Dr) calculadas sobre as médias ao longo dos perfis foram de $\mathrm{Dr}=-0,26$ para o perfil $\mathrm{I}$ e $\mathrm{Dr}=0,80$ para o perfil II. Estes resultados mostram que as diferenças numéricas entre os dados obtidos pelos dois métodos estão dentro de uma faixa de variação aceitável para o que se buscou no presente trabalho. 
Os resultados dos dois experimentos de campo podem ser visualizados nas figuras 12 e 13. As linhas de tendência, tipo regressão linear, mostram o comportamento dos dados, obtidos pelos dois métodos em função da profundidade, em relação aos dados obtidos. 
Tabela 6 - Primeiro experimento de campo, comparação das lâminas de água calculadas pelo método gravimétrico (LG) com as lâminas de água determinadas pelo HIDRO SAVER (LHS). Dados obtidos em amostras indeformadas no PODZÓLICO AMARELO perfil I.

\begin{tabular}{|c|c|c|c|c|c|c|c|c|c|c|c|c|}
\hline $\begin{array}{l}\text { Prof. } \\
\text { cm }\end{array}$ & $\begin{array}{l}\text { PU } \\
\text { g }\end{array}$ & $\begin{array}{c}\text { PS } \\
\text { g }\end{array}$ & $\begin{array}{c}\mathrm{U} \\
\mathrm{g} \cdot \mathrm{g}^{-1}\end{array}$ & $\begin{array}{c}\mathrm{Da} \\
\mathrm{g} \cdot \mathrm{cm}^{-3}\end{array}$ & $\begin{array}{c}\theta \\
\mathrm{cm}^{3} \cdot \mathrm{cm}^{-3}\end{array}$ & $\begin{array}{l}\mathrm{H} \\
\mathrm{cm}\end{array}$ & $\begin{array}{l}\mathrm{LG} \\
\mathrm{cm}\end{array}$ & $\begin{array}{l}\mathbf{L G} \\
\mathbf{m m}\end{array}$ & $\begin{array}{c}\text { HSU } \\
\mathrm{mm}\end{array}$ & $\begin{array}{l}\text { HSS } \\
\text { mm }\end{array}$ & $\begin{array}{c}\text { LHS } \\
\text { mm }\end{array}$ & $\begin{array}{l}\mathrm{DT} \\
\%\end{array}$ \\
\hline 3,30 & 94,67 & 85,26 & 0,11038 & $\overline{1,40}$ & 0,15436 & 3,30 & 0,5094 & 5,10 & 4,83 & 9,93 & 5,11 & $-0,20$ \\
\hline 6,60 & 97,05 & 88,02 & 0,10335 & 1,44 & 0,14813 & 3,30 & 0,4888 & 4,89 & 4,07 & 9,07 & 5,00 & $-2,25$ \\
\hline 9,90 & 114,81 & 105,31 & 0,09021 & 1,73 & 0,15584 & 3,30 & 0,5143 & 5,14 & 3,44 & 8,55 & 5,11 & 0,58 \\
\hline 13,20 & 116,80 & 106,62 & 0,09551 & 1,75 & 0,16708 & 3,30 & 0,5514 & 5,51 & 3,55 & 9,10 & $\mathbf{5 , 5 5}$ & $-0,72$ \\
\hline 16,50 & 105,32 & 96,17 & 0,09518 & 1,58 & 0,15010 & 3,30 & 0,4953 & 4,95 & 4,18 & 9,14 & 4,96 & $-0,20$ \\
\hline 23,10 & 109,44 & 98,87 & 0,10715 & 1,62 & 0,17331 & 3,30 & 0,5719 & 5,72 & 2,66 & 8,38 & 5,72 & $-0-$ \\
\hline 26,40 & 114,02 & 102,49 & 0,11271 & 1,68 & 0,18903 & 3,30 & 0,6238 & 6,24 & 2,89 & 9,18 & 6,29 & $-0,80$ \\
\hline 29,70 & 103,04 & 92,95 & 0,10850 & 1,52 & 0,16552 & 3,30 & 0,5462 & 5,46 & 3,89 & 9,38 & 5,49 & $-0,55$ \\
\hline 33,00 & 109,17 & 98,09 & 0,11318 & 1,61 & 0,18187 & 3,30 & 0,6002 & 6,00 & 3,63 & 9,66 & 6,03 & $-0,50$ \\
\hline 36,30 & 111,03 & 99,02 & 0,12124 & 1,62 & 0,19693 & 3,30 & 0,6499 & 6,50 & 3,89 & 10,38 & 6,49 & 0,15 \\
\hline 39,60 & 109,65 & 98,22 & 0,11636 & 1,61 & 0,18750 & 3,30 & 0,6188 & 6,19 & 3,74 & 9,92 & 6,18 & 0,16 \\
\hline 42,90 & 114,75 & 101,83 & 0,12693 & 1,67 & 0,21202 & 3,30 & 0,6997 & 7,00 & 2,66 & 9,71 & 7,05 & $-0,71$ \\
\hline 46,20 & 113,94 & 101,59 & 0,12152 & 1,67 & 0,20251 & 3,30 & 0,6683 & 6,68 & 3,66 & 10,38 & 6,72 & $-0,60$ \\
\hline 49,50 & 118,07 & 105,05 & 0,12384 & 1,72 & 0,21358 & 3,30 & 0,7048 & 7,05 & 3,33 & 10,49 & 7,16 & $-1,56$ \\
\hline 52,80 & 115,85 & 103,39 & 0,12050 & 1,70 & 0,20429 & 3,30 & 0,6741 & 6,74 & 3,00 & 9,69 & 6,70 & 0,59 \\
\hline 56,10 & 120,15 & 105,72 & 0,13663 & 1,73 & 0,23671 & 3,30 & 0,7812 & 7,81 & 2,44 & 10,25 & 7,81 & -0 \\
\hline 59,40 & 115,05 & 101,68 & 0,13152 & 1,67 & 0,21927 & 3,30 & 0,7236 & 7,24 & 2,78 & 10,03 & 7,25 & $-0,14$ \\
\hline 62,70 & 115,38 & 101,98 & 0,13136 & 1,67 & 0,21976 & 3,30 & 0,7252 & 7,25 & 3,40 & 10,58 & 7,18 & 0,96 \\
\hline 66,00 & 108,12 & 95,08 & 0,13731 & 1,56 & 0,21397 & 3,30 & 0,7061 & 7,06 & 2,74 & 9,77 & 7,03 & 0,42 \\
\hline 69,30 & 116,94 & 101,31 & 0,15428 & 1,66 & 0,25640 & 3,30 & 0,8461 & 8,46 & 2,78 & 11,43 & 8,66 & $-2,36$ \\
\hline 72,60 & 111,76 & 98,58 & 0,13387 & 1,62 & 0,21610 & 3,30 & 0,7131 & 7,13 & 2,96 & 10,06 & 7,10 & 0,42 \\
\hline 75,90 & 114,48 & 100,55 & 0,13852 & 1,65 & 0,22846 & 3,30 & 0,7539 & 7,54 & 2,63 & 10,18 & 7,55 & $-0,13$ \\
\hline 79,20 & 118,10 & 104,69 & 0,12812 & 1,72 & 0,21998 & 3,30 & 0,7259 & 7,26 & 3,00 & 10,10 & 7,10 & 2,20 \\
\hline 82,50 & 113,56 & 99,56 & 0,14084 & 1,63 & 0,22958 & 3,30 & 0,7576 & 7,58 & 2,50 & 10,10 & 7,60 & $-0,26$ \\
\hline 85,80 & 118,39 & 103,79 & 0,14068 & 1,70 & 0,23950 & 3,30 & 0,7904 & 7,90 & 2,22 & 10,21 & 7,99 & $-1,14$ \\
\hline 89,10 & 113,77 & 99,46 & 0,14386 & 1,63 & 0,23469 & 3,30 & 0,7745 & 7,74 & 2,74 & 10,40 & 7,66 & 1,03 \\
\hline 92,40 & 111,83 & 97,33 & 0,14893 & 1,60 & 0,23781 & 3,30 & 0,7848 & 7,85 & 2,37 & 10,25 & 7,88 & $-0,38$ \\
\hline 95,70 & 118,23 & 103,61 & 0,14112 & 1,70 & 0,23983 & 3,30 & 0,7914 & 7,91 & 2,48 & 10,51 & 8,03 & $-1,52$ \\
\hline
\end{tabular}

Correl - 0,998

Volume do cilindro $=60,96 \mathrm{~cm}^{3}$

(1) -Valores médios de três repetições.

LG - Lâmina de água calculada pelo método gravimétrico.

LHS - Lâmina de água determinada pelo HIDRO SAVER.

HSU - Lâmina de água determinada pelo HIDRO SAVER a partir do solo úmido.

HSS - Lâmina de água determinada pelo HIDRO SAVER a partir do solo seco em estufa.

Dr - Diferença relativa entre os dados obtidos pelos dois métodos. 
Tabela 7 - Segundo experimento de campo, comparação das lâminas de água calculadas pelo método gravimétrico (LG) com as lâminas de água determinadas pelo HIDRO SAVER (LHS). Dados obtidos em amostras indeformadas no PODZÓLICO AMARELO do perfil II.

\begin{tabular}{|c|c|c|c|c|c|c|c|c|c|c|c|c|}
\hline $\begin{array}{c}\text { Prof. } \\
\mathrm{cm}\end{array}$ & $\begin{array}{c}\mathrm{PU} \\
\mathrm{g}\end{array}$ & $\begin{array}{c}\text { PS } \\
g\end{array}$ & $\begin{array}{c}U \\
g . g^{-1}\end{array}$ & $\begin{array}{c}\mathrm{da} \\
{\mathrm{g} . \mathrm{cm}^{-3}}^{-3}\end{array}$ & $\begin{array}{c}\mathrm{q} \\
\mathrm{cm}^{3} \cdot \mathrm{cm}^{-3}\end{array}$ & $\begin{array}{c}\mathrm{H} \\
\mathrm{cm}\end{array}$ & $\begin{array}{l}\mathrm{LG} \\
\mathrm{cm}\end{array}$ & $\begin{array}{l}\mathbf{L G} \\
\mathrm{mm}\end{array}$ & $\begin{array}{l}\text { HSU } \\
\mathrm{mm}\end{array}$ & $\begin{array}{l}\mathrm{HSS} \\
\mathrm{mm}\end{array}$ & $\begin{array}{l}\text { LFS } \\
\mathbf{m m}\end{array}$ & $\begin{array}{l}\mathrm{Dr} \\
\%\end{array}$ \\
\hline 3,30 & 83,80 & 77,59 & 0,08013 & 1,27 & 0,10195 & 3,30 & 0,3364 & 3,36 & 5,83 & $\overline{16}$ & 3,33 & 0,89 \\
\hline 6,60 & 91,57 & 84,75 & 0,08047 & 1,39 & 0,11188 & 3,30 & 0,3692 & 3,69 & 5,07 & 8,77 & 3,70 & $-0,27$ \\
\hline 9,90 & 92,02 & 84,67 & 0,08695 & 1,39 & 0,12068 & 3,30 & 0,3982 & 3,98 & 5,14 & 9,10 & 3,96 & 0,50 \\
\hline 13,20 & 111,11 & 101,61 & 0,09357 & 1,67 & 0,15589 & 3,30 & 0,5145 & 5,14 & 2,63 & 7,70 & 5,07 & 1,36 \\
\hline 16,50 & 112,61 & 102,85 & 0,0 & 1,69 & $\mathbf{0}$, & 3,30 & 83 & 5,28 & 3,11 & 8,21 & 11 &, 22 \\
\hline 19,80 & 115,53 & 98,39 & 0,17420 & 1,61 & 17 & 3,30 & 0,9279 & 9,28 & 0,00 & 9,21 & 9,21 & 0,75 \\
\hline 23,10 & 113,17 & 102,84 & 0,10051 & 1,69 & 51 & 3,30 & 0,5594 & 5,59 & 2,44 & 8,07 & 5,62 & $-0,54$ \\
\hline 26,40 & 110,78 & 100,51 & 0,10221 & 1,65 & 0,16842 & 3,30 & 0,5558 & 5,56 & 2,78 & 8,25 & 5,48 & 1,44 \\
\hline 29,70 & 114,69 & 103,23 & 0,11089 & 1,69 & 94 & 3,30 & 0,6202 & 6,20 & 1,96 & 8,21 & 6,25 & $-0,81$ \\
\hline 33,00 & 113,79 & 102,23 & 314 & 1,68 & 69 & 3,30 & 0,6260 & 6,26 & 1,92 & 8,14 & 6,22 & 0,64 \\
\hline 36,30 & 113,34 & 101,67 & 68 & 1,67 & 44 & 3,30 & 0,6317 & 6,32 & 2,66 & 9,05 & 6,38 & $-0,95$ \\
\hline 39,60 & 1 & 20 & & 8 & & 0 & 8 & 5,93 & 2,94 & 8,82 & 5,88 & 0,84 \\
\hline 42,90 & 1 & 10 & & 1,75 & & 0 & & 6,84 & 50 & 32 & 6,83 & 15 \\
\hline 46,20 & 1 & 105,46 & & 1,73 & & 0 & & & 15 & 4 & 8 & $-0,31$ \\
\hline 49,50 & 107,72 & 97,39 & 0,10607 & 1,60 & 40 & 3,30 & 0,5590 & 5,59 & 2,26 & 7,96 & & $-1,97$ \\
\hline 52,80 & 118,05 & 106,45 & 0,10900 & 1,75 & 37 & 3,30 & 0,6282 & 6,28 & 1,67 & 7,66 & 5,99 & 4,62 \\
\hline 56,10 & 114,84 & 103,14 & 0,11341 & 1,69 & 187 & 3,30 & 0,6332 & 6,33 & 2,37 & 8,55 & 6,18 & 2,37 \\
\hline 59,40 & 105,38 & 94,39 & 0,11645 & 1,55 & 0,18028 & 3,30 & 0,5949 & 5,95 & 2,72 & 8,49 & $\mathbf{5 , 7 7}$ & 3,02 \\
\hline 62,70 & 110,19 & 97,36 & 0,13176 & 1,60 & 0,21041 & 3,30 & 0,6944 & 6,94 & 1,07 & 7,99 & 6,92 & 0,29 \\
\hline 66,00 & 111,40 & 98,42 & 0,13187 & 1,61 & 0,21298 & 3,30 & 0,7028 & 7,03 & 2,22 & 9,14 & 6,92 & 1,56 \\
\hline 69,30 & 109,55 & 95,68 & 0,14505 & 1,57 & 0,22753 & 3,30 & 0,7508 & 7,51 & 1,50 & 9,05 & 7,55 & $-0,53$ \\
\hline
\end{tabular}

Correl - 0,9973

Volume do cilindro $=60,96 \mathrm{~cm}^{3}$

(1) - Valores médios dos resultados com corpos de provas.

LG - Lâmina de água calculada pelo método gravimétrico.

LHS - Lâmina de água determinada pelo HIDRO SAVER.

HSU - Lámina de água determinada pelo HIDRO SAVER a partir do solo úmido.

HSS - Lâmina de água determinada pelo HIDRO SAVER a partir do solo seco em estufa.

DrDiferença relativa entre os dados obtidos pelos dois métodos. 


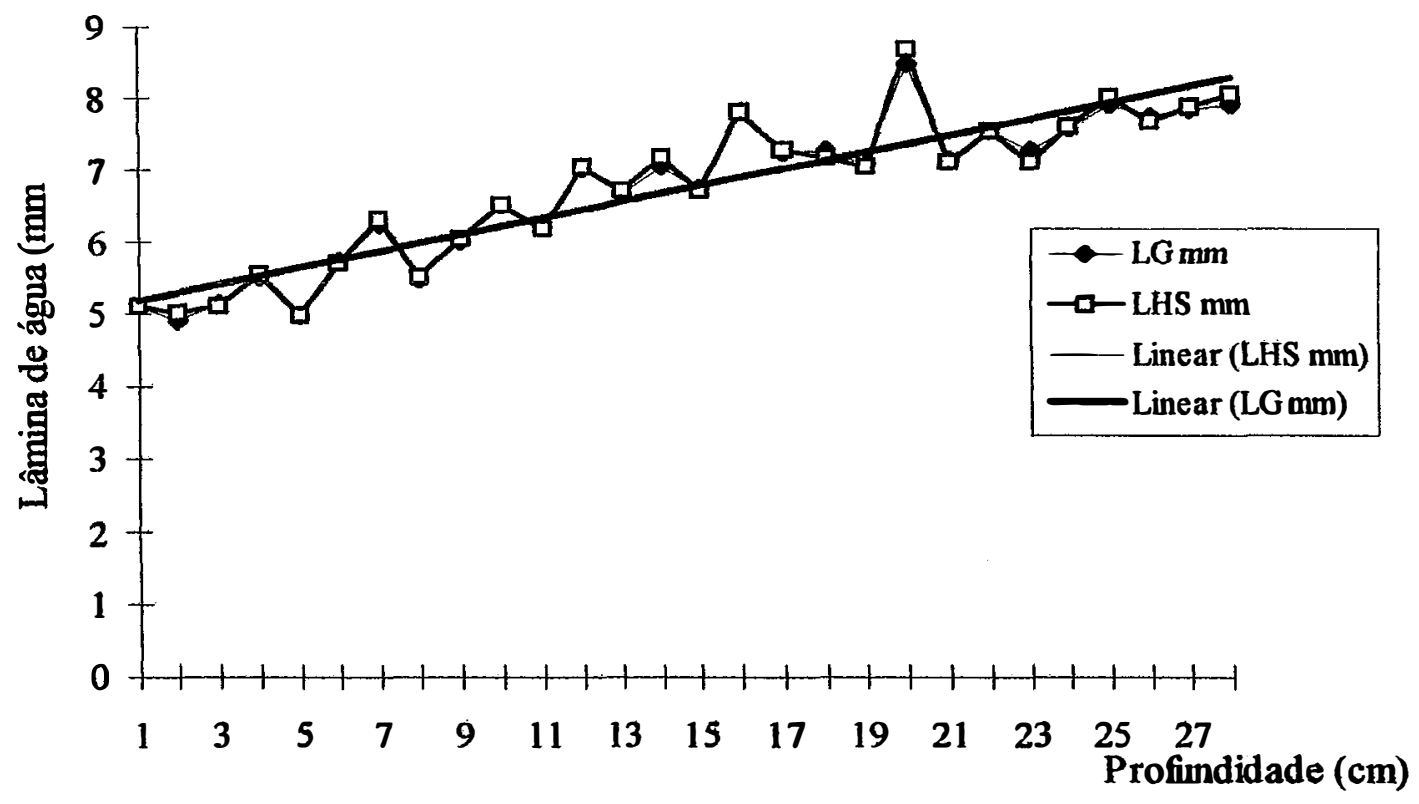

Figura 12 - Variação da urnidade em função da profundidade no experimento de campo, perfil. l, média de três repetições.

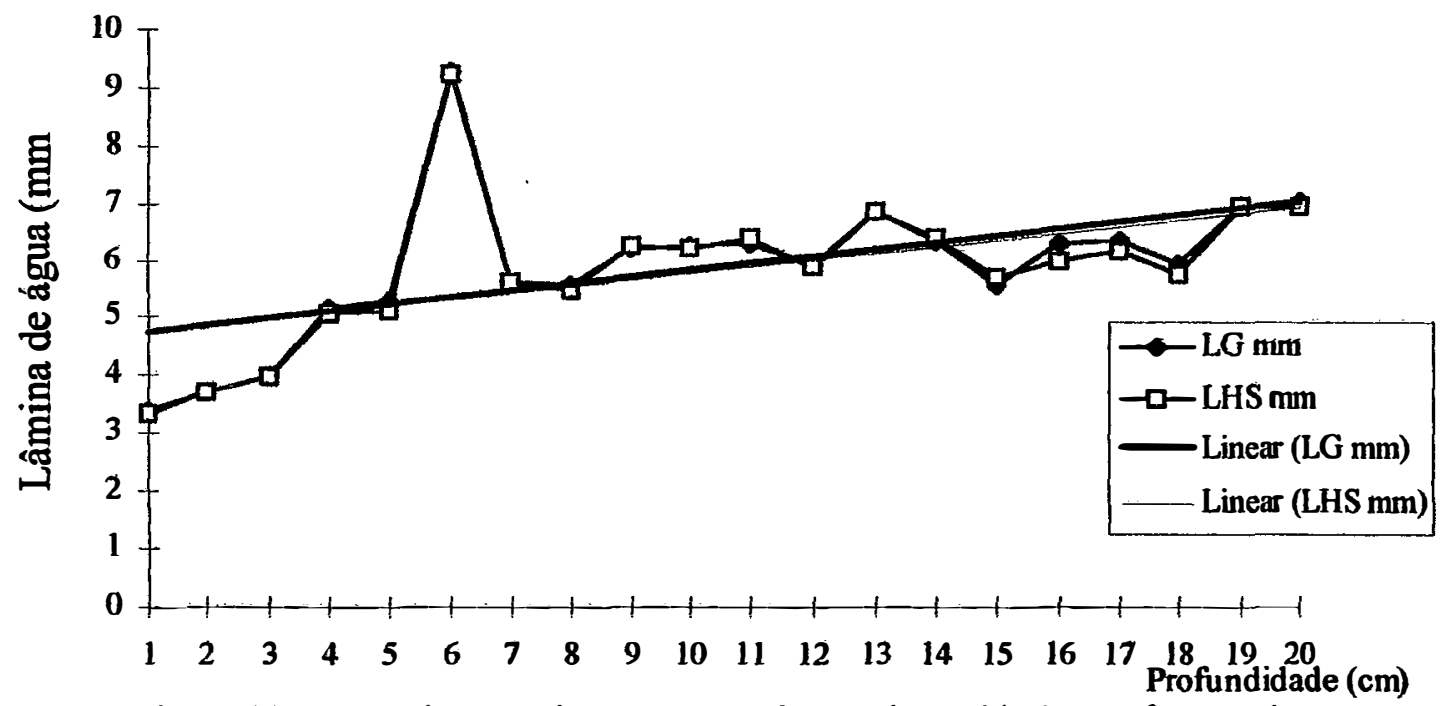

Figura 13 - Experimento de campo, variação da umidade em fumção da profundidade, perfil ll valores média de três repetições. 


\section{CONCLUSÕES.}

O HIDRO SAVER, tal como proposto, apresenta-se como um equipamento apropriado para a determinação da lâmina d'água de uma amostra de solo qualquer, em condições de laboratório e de campo.

O manuseio do HIDRO SAVER não requer especialização do operador.

Os tempos de determinação da lâmina de água a ser caculada pelos outros métodos convencionais aqui testados são, em média, 280 vezes maiores do que os obtidos pelo HIDRO SAVER.

O HIDRO SAVER, não apresentou custos com manutenção.

Os tempos de 30 e 60 segundos como limites de frequêencia da liberação de bolhas (estabilização do HIDRO SAVER), podem ser considerados como suficientes e indicados para os solos estudados.

A arquitetura do instrumento é eficiente para trabalhar tanto com amostras estruturadas quanto com amostras desestruturadas.

A esponja na célula de distribuição é eficiente para promover um bom contato de coluna de água com o solo.

O HIDRO SAVER apresentou precisão em nível de centésimos de milimetro, nos testes com corpos de prova. 


\section{REFERÊNCIAS BIBLIOGRÁFICAS}

ABELE, G.; McKIM, H. L.; BROCKETTE, B. Mass Water balance during spray irrigation with waste at Deer Greek Lake and treatment site. Rep. 79-29, U.S. Army Corps of Eng., Hannover, N. H., 1979.

ALVES, A. J. O.; Classificação de Aptidão Agrícola dos Solos da Estação Experimental de Cana-de-açúcar de Carpina. Recife: Caderno ÔMEGA n6 Série Agronomia V. 1 n¹. p. 35-55, 1994.

ALWAY, F. J. \& McDOLE, G. R. Relation of the water-retaining capacity of soil to its hydroscopic coefficient. J. Agr. Res., Washington, 9: 27-71, 1917.

BARROS FERRAZ, E. S. 1968 - Departamento da evapotranspiração real pela moderação de nêutrons. Tese de doutoramento. ESALQ/USP.

BOUYOUCOS, G. J. Rapid determination of the moisture content of soil. Soil Science, Madison, 24: 651-2. 1926.

Rapid Determination of soil moisture by alcohol. Soil science, Madison, 25: 375.6 .1927$.

Determining soil moisture rapidly and accurately by methyl alcohol. Amer. Soc. Agron. J. 20: 82-3, January, 1928. 
-------. Evaporating water with burning alcohol as a rapid means of determining moisture content of soil, Soil Science, Madison, 44: 377-83. 1937.

CARNEIRO, C. \& De JONG, E. In situ determination of slope of the calibration curve of a neutron probe using a volumetric technique. Soil Sci., 139:250-54, 1986.

CASSEL, D. K. \& NIELSEN, D.R. Field capacity and available water capacity. In: KLUTE, A.; ed. Methods of soil analysis. Part. I. Physical and mineralogical methods. Madison, American Society of Agronomy, Soil Science Society of America, 1986, p. 901-26.

COLMAN, E. A. A laboratory procedure for determining the field capacity of soils. Soil Science, Madison, 67: 277-83, 1947.

CRUCIANI, D. 1971 - “Aplicação do método da moderação de nêutrons no estudo do balanço hídrico em solo cultivado com cana-de-açúcar”. Tese de Doutoramento, ESALQ/USP.

ENCARNAÇÃO , F. A. F. Patente de invenção de um "HIDROCAPACITOR Yo". Classificação Internacional GO1N19/10 RPI 1050/91, Brasil 1988.

ENCARNAÇÃO, F. A. F, Nova técnica para calibração de sonda de nêutrons pelo método volumétrico. Pesq. agropec. bras., Brasília, 26 (7):1107-1112, jun. 1991.

GARDNER, W. H. Water content. In Black, C. A. ed. Methods of soil analysis. Madson American Society of Agronomy, 1965. pp. 82-127.

HILLEL, D. Soil and water: physical principles and processes. Academic Press, New York, p. 73-77, 1971. 
JACOMINE, P. K. T.; CAVALCANTE, A. C.; BURGOS, N. et al. Levantamento Exploratório - Reconhecimento de Solos do Estado de Pernambuco. Recife: MA - DNPEA; SUDENE - DNR, 1973. v. 1 (Boletim técnico, 26).

JENSEN, P. A. \& SOMMER, E. 1967 - "Scintillation techniques in soil-moisture and density measurements. Proceedings of the Istambul Symposium, 12-16 June, International Atomic Energy Agency. Vienna.

KELLEY, O. J. e HUNTER, A. S. A Comparison of methods of measuring soil moisture under field conditions. Am. Soc. Agron, J. 38. 758-84, 1946.

KLUTE, A. \& GARDNER, W. R. Tensiometer response time. Soil Science, Baltimore, 93 (1): 204-207, 1962.

KOFFLER, N. F., LIMA, J. F. W. F.; LACERDA, M. F. et al. Caracterização Edafoclimática das Regiôes Canavieiras do Brasil: Pemambuco. Piracicaba: IAA-PLANALSUCAR, 1986. 78p.

LIBARDI, P. L. Determinação da condutância hidráulica e da pressão de borbulhamento das cápsulas porosas para tensiômetros. Depto. Física e Meteorologia, LFM-715, ESALQ/USP. Piracicaba, SP, 1987. Mimeografado, 5p.

LIBARDI, P. L. Dinâmica da água no sistema solo-planta-atmosfera. CENA/USP, Piracicaba, SP, 1984. 232p.

MARCOS, Z. Z. Estrutura, agregação e água no solo. Escola Superior de Agricultura "Luiz de Queiroz", Piracicaba, SP, 1968. 55p. (Tese de Mestrado)

MEDINA, H. P. \& GROHMANN, F. 1962 - "Características de umidade dos 
principais solos do Estado de São Paulo”. Bragantia, 21,: 285-295.

MEDINA, H. P. \& GROHMANN, F. 1966 - "Disponibilidade de água em alguns solos sob cerrado". Bragantia, 25: 65-76.

MILLER, R. J., R. B. SMITH, and J. W. Biggar. 1974. Soil water content: microwave oven method. Soil Sci. Soc. Am. Proc. 38:535-537.

MORETTI FILHO, J. O Tensiômetro no controle da água de irrigação. Bol. Técnico, 9: E.S.A. “Luiz de Queiroz “, Out. 1962.

OGANESYAN, A. P. A simple field method for determining soil moisture. Soviet Soil Science, 4 April, 1958.

OLITTA, A. F. L. Construção de tensiômetros para controle de irrigação. IV Congresso de Engenharia Agricola, SBEA, Viçosa, MG, 1974.

PAES DE CAMARGO, A.; GROHMANN, F.; PAES DE CAMARGO, M. B. Tensiômetro simples de leitura direta. Pesq. agropec. bras., 17(12): 1763-1772, 1982.

PHILLIPS, R. E., C. R. JENSEN, \& D. Kirkham. 1960. Use of radiation equipment for plow-layer density and moisture. Soil Sci. 89:2-7.

REICHARDT, K. Processos de transferência no sistema solo-planta-atmosfera. Campinas, SP. Fundação Cargill, 268 p., 1975.

Processos de transferência no sistema solo-planta-atmosfera. Campinas. Fundação Cargill, 1985. 445 p. 
RICHARDS, L. A. \& GARDNER, W. Tensiommeters for measuring the capillary tension of soil water. J. Amer. Soc. Agron., 28: 352-358, 1936.

RICHARDS, L. A. \& O’NEAL, R. Some field observations with tensiommeters. Proc. Soil Sci. Am. 1: 71-91, 1937.

ROSE, C. W. Agricultural Physics. Oxford, 1966. Pergamon-Press, 230p.

SALATI, E. 1960 - “Introdução ao estudo da água do solo pela moderação de nêutrons”. Tese de Livre Docência, ESALQ/USP, Piracicaba, SP.

SCARDUA, R. 1972 - "Porosidade Livre de água de dois solos do Município de Piracicaba, SP. “Tese de Mestrado, ESALQ/USP, Piracicaba.

SCHMUGGE, T. J.; JACKSON, T. J.; McKIM, H. L. Survey of methods for soil moisture determination. Water Resour. Res., 16: 961-979, 1980.

SHAW, W. D. e ARBLE, W. C. Bibliography on methods for determining soil moisture. College of Eng. And Architecture. PENN State, Univ. 629 ref. 1959.

TAYLOR, S. A. 1955. Field determinations of soil moisture. Agric. Eng. 36:654-659.

TOPP, G. C. \& ZEBCHUCK, W. The determination of soil-water desorption curves for soil cores. Can. J. Soil Sci., Ottawa, 59: 19-26, 1979.

TOWER, G. D. Theory of time response of tensiommeters. J. Soil Sci., 31: 607-621, 1980.

VEIHMEYER, F. J. \& HENDRICKSON, A. H. The moisture equivalent as a measure of the field capacity of soils. Soil Sci., Baltimore, 32: 181-93, 1931.

. Methods of measuring field capacity and wilting percentages of soil. 
Soil Sci., Baltimore, 68: 75-94, 1949.

VILLA NOVA, N. A.; REICHARDT, K.; LIBARDI, P. L. \& MORAES, S. O. Direct reading "airpocket tensiommeter". Soil Technology, Cremlingen, 2: 403-407, 1989.

VILLA NOVA, M. S.; VILLA NOVA, N. A.; OLIVEIRA, A. S. \& REICHARDT, K. Performance and test of a direct reading "air-pcket" tensiometer. Short Communication, Cremlinger, 5; 283-287, 1992 
APÊNDICE 
Tabela 8 - Classificação dos perfis utilizados nos experimentos de campo.

Perfil Classificação

1. PODZÓLICO AMARELO DISTRÓFICO com fragipan A procminente textura média/argilosa fase floresta subcaducifólia relevo plano.

2. PODZÓlICO AMARELO DISTRÓFICO com fragipan A proeminente textura média/argilosa fase floresta subcaducifólia relevo suave ondulado.

Tabela 9 - Características morfológicas dos Podzólicos Amarelos dos perfis.

\begin{tabular}{|c|c|c|c|c|c|}
\hline Horiz & $\begin{array}{l}\text { Prof. } \\
\text { (cm) }\end{array}$ & $\begin{array}{l}\text { Cor úmida } \\
\text { Horiz. Moscueando }\end{array}$ & Estrutura (1) & Consistência (2) & $\begin{array}{l}\text { Caract. adicionais } \\
\text { (3) }\end{array}$ \\
\hline \multicolumn{6}{|c|}{ PODZŹLLICO AMARELO (Perfil 1) } \\
\hline $\begin{array}{l}\mathrm{Ap} \\
\mathrm{A} 2 \\
\mathrm{A3} \\
\mathrm{AB} \\
\mathrm{Btx}\end{array}$ & $\begin{array}{c}0-20 \\
20-50 \\
50-97 \\
97-132 \\
132-200\end{array}$ & $\begin{array}{l}\text { I0YR 3/1 - } \\
\text { 10YR 3/1 - } \\
\text { 10YR 3/2 - } \\
\text { 10YR 4/2 10YRS/6 } \\
\text { 10YR } 5 / 6 \text { - }\end{array}$ & $\begin{array}{l}\text { fra.peq. a med. gran; fr.peq. a med.blo. } \\
\text { subang. } \\
\text { maciça } \\
\text { fra.peq. a med.blo.subang. } \\
\text { fra.peq. a med.blo.subang. } \\
\text { fra.peq. a med.blo.subang. com partes maciças }\end{array}$ & $\begin{array}{l}\text { duro;mui.fi.;lig.plas. e lig.peg. } \\
\text { mui.duro;fir.;lig.plas. e lig.peg. } \\
\text { mui.duro;fri.;lig.plas. e lig.peg. } \\
\text { duro;fri.;plas. e peg. } \\
\text { mui.duro;fir.;plas. e peg. }\end{array}$ & $\begin{array}{l}\text { tra.clara e pl. } \\
\text { tra.gra. e pl. } \\
\text { tra.gra. e pl. } \\
\text { tra.gra. e pl. } \\
\text { Ceros.com. e fra. }\end{array}$ \\
\hline \multicolumn{6}{|c|}{ PODZÓLICO AMARELO (Perfil 2) } \\
\hline $\begin{array}{l}\text { Ap } \\
\text { A2 } \\
\text { A3 } \\
\text { AB } \\
\text { Btx }\end{array}$ & $\begin{array}{c}0-19 \\
19-53 \\
53-101 \\
101-130 \\
130-200\end{array}$ & $\begin{array}{l}\text { IOYR 3/2 } \\
\text { 10YR 3/2 } \\
\text { 10YR 4/2 } \\
\text { 10YR 4/3 } 10 \text { YR5/8 } \\
\text { 10YR 5/6 2,5YR4/6 }\end{array}$ & $\begin{array}{l}\text { fra.peq.a med. gran.; fr.peq. a med.blo. subang. } \\
\text { maciça } \\
\text { fra.peq. a med.blo.subang. } \\
\text { fra.peq. a med.blo.subang. com partes maciças } \\
\text { fra.peq. a med.blo.subang. com partes macipas }\end{array}$ & $\begin{array}{l}\text { lig.duro;mui.fri.;ig.pla. o lig.peg. } \\
\text { mui.duro;fri.;lig.pla. e lig.peg. } \\
\text { duro;fri.;pla. e peg. } \\
\text { duro a mui.duro;fri.;pla. e peg. } \\
\text { mui.duro a ext.duro;fir.;mui.pla. e } \\
\text { neg. }\end{array}$ & $\begin{array}{l}\text { tra.clara e pl. } \\
\text { tra.gra. e pl. } \\
\text { tra.gra. e pl. } \\
\text { tra.gra. e pl. } \\
\text { Ceros.com. e for. }\end{array}$ \\
\hline
\end{tabular}

\section{Coloração variegada}

fra.- fraca; mod.- moderada; for.- forte; peq.- pequena; med.- média; gra.- grande; gran.-granular;blo.blocos; subang.- subangulares; ang.- angulares; lig.- ligeiramente; mui.- muito; ext.- extremamente; fri.friável; fir.- firme; pla.- plástico; peg.- pegajoso; tra.- transiçao; gra.- gradual; abr.- abrupta; pl.- plana; ceros.- cerosidade; com.- comum; fra.- fraca; mod.- moderada; for.- forte. 
Tabela 10 - Propriedades física dos perfis utilizados no experimento de campo.

\begin{tabular}{|c|c|c|c|c|c|c|c|c|c|c|c|c|c|c|c|c|}
\hline Hori & $\begin{array}{c}\text { Prof. } \\
(\mathrm{cm})\end{array}$ & $\begin{array}{c}\text { Casca- } \\
\text { lho\% }\end{array}$ & $\begin{array}{c}\text { Terra } \\
\text { fina } \\
\%\end{array}$ & $\begin{array}{c}\text { Areia } \\
\text { grossa } \\
\%\end{array}$ & $\begin{array}{c}\text { Areia } \\
\text { fina } \\
\%\end{array}$ & $\begin{array}{c}\text { Silte } \\
\%\end{array}$ & $\begin{array}{c}\text { Angila } \\
\%\end{array}$ & $\begin{array}{c}\text { Siltel } \\
\text { Argila }\end{array}$ & $\begin{array}{c}\text { Classe } \\
\text { textural }\end{array}$ & $\begin{array}{c}\text { Argila } \\
\text { natural } \\
\%\end{array}$ & $\begin{array}{c}\text { Grau de } \\
\text { flocul. }\end{array}$ & $\begin{array}{c}D_{g} \\
\mathbf{g}^{\prime} / \mathrm{cm}^{3}\end{array}$ & $\begin{array}{c}\text { Dp } \\
\mathrm{g} / \mathrm{cm}^{3}\end{array}$ & $\begin{array}{c}\text { Porosida- } \\
\text { de total } \\
\%\end{array}$ & $\begin{array}{c}\text { Umid. } \\
-1,5 \\
\mathrm{MPa}\end{array}$ & $\begin{array}{c}\text { Umid } \\
-0,03 \\
\mathrm{MPa}\end{array}$ \\
\hline
\end{tabular}

\section{PODZÓliCO AMARELO (Perfil 1)}

\begin{tabular}{|c|c|c|c|c|c|c|c|c|c|c|c|c|c|c|c|c|}
\hline $\mathrm{Ap}$ & $0-20$ & 1 & 99 & 54 & 23 & 10 & 13 & 0.77 & fr.ar & 6 & 54 & 1.54 & 2.61 & 41 & 5.6 & 8.6 \\
$\mathrm{AZ}$ & $20-50$ & 1 & 99 & 53 & 24 & 8 & 15 & 0.53 & fr.ar & 6 & 60 & 1.58 & 2.65 & 40 & 5.4 & 8.1 \\
$\mathrm{~A} 3$ & $50-97$ & 2 & 98 & 50 & 21 & 7 & 22 & 0.32 & fr.arg.ar & 12 & 45 & 1.47 & 2.69 & 45 & 5.7 & 10.2 \\
$\mathrm{AB}$ & $97-132$ & 2 & 98 & 45 & 19 & 6 & 30 & 0.20 & fr.arg.ar & 10 & 67 & 1.46 & 2.69 & 44 & 9.1 & 12.4 \\
$\mathrm{BEx}$ & $132-200$ & 1 & 99 & 31 & 18 & 5 & 46 & 0.11 & arg.ar & 5 & 89 & 1.58 & 2.71 & 42 & 13.8 & 18.5 \\
\hline
\end{tabular}

PODZólico AMARELO (Perfil 2)

\begin{tabular}{|c|c|c|c|c|c|c|c|c|c|c|c|c|c|c|c|c|}
\hline $\mathrm{Ap}$ & $0-19$ & 1 & 99 & 52 & 24 & 10 & 14 & 0.71 & fr.ar & 6 & 57 & 1.45 & 2.66 & 46 & 5.3 & 8.8 \\
$\mathrm{~A} 2$ & $19-53$ & 2 & 98 & 54 & 22 & 9 & 15 & 0.60 & fr.ar & 4 & 73 & 1.60 & 2.66 & 40 & 5.4 & 8.1 \\
$\mathrm{A3}$ & $53-101$ & 3 & 97 & 46 & 22 & 8 & 24 & 0.33 & fr.arg.ar & 8 & 67 & 1.55 & 2.65 & 42 & 7.4 & 11.2 \\
$\mathrm{AB}$ & $101-130$ & 2 & 98 & 39 & 16 & 8 & 37 & 0.22 & arg.ar & 18 & 51 & 1.47 & 2.65 & 44 & 10.5 & 15.5 \\
$\mathrm{Btx}$ & $130-200$ & 2 & 98 & 25 & 12 & 11 & 52 & 0.21 & arg. & 4 & 92 & 1.60 & 2.67 & 40 & 15.4 & 20.0 \\
\hline
\end{tabular}

A distribuição granulométrica ao longo do perfil se apresenta ilustrada em gráficos cumulativos, na figura 14.

Os Podzólicos Amarelos apresentam um horizonte superficial de textura média e um horizonte subsuperficial argiloso, com o horizonte Ap apresentando teores de argila entre 13 e 19\%, aumentando gradativamente para um B com teores de argila acima de $46 \%$ e grau de floculação acima de $89 \%$. Este aumento do teor de argila mais pronunciado a partir do horizonte $A B$, é responsável por uma relação textural $B / A$, que varia entre 1,10 e 2,31, caracterizando o horizonte $B$ textural. $O$ silte nestes solos apresenta valores baixos ao longo do perfil, assumido no horizonte superficial Ap valores em torno de $10 \%$, diminuindo com a profundidade até o horizonte subsuperficial $\mathrm{Bt}$, onde tornam a aumentar, chegando atingir $17 \%$. 

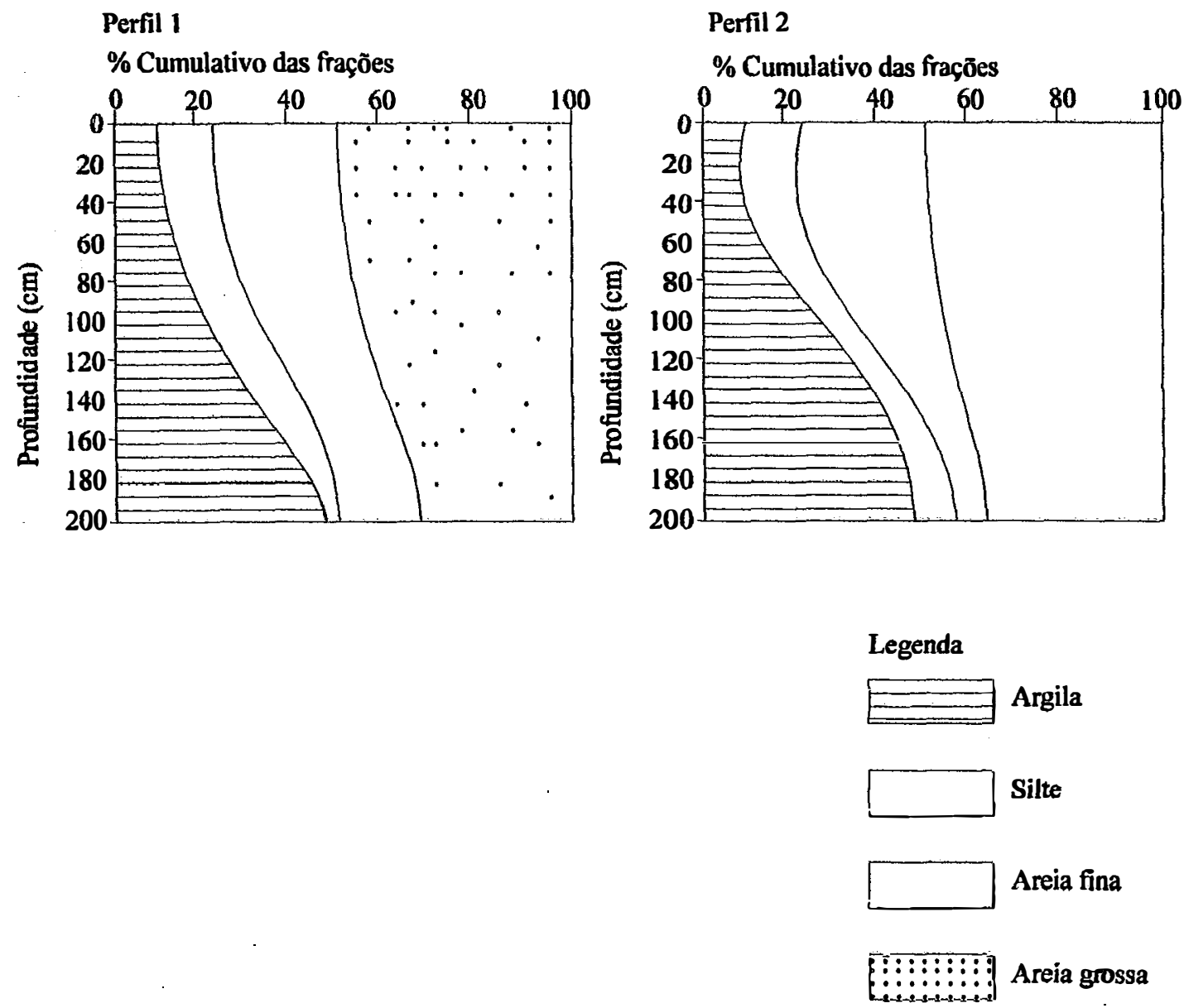

Figura 14 - Gráficos cumulativos das frações granulométricas.

Nos Podzólicos Vermelho-amarelos, os teores de argila tendem a aumentar com a profundidade até o horizonte subsuperficial $\mathrm{B}$, havendo a tendência de uma ligeira diminuição nestes teores, no horizonte $C$, definindo curvas típicas de $B$ textural, em todos os perfis. O horizonte Ap, apresenta valores para os teores de argila, entre 17 e $27 \%$, transitando para um Bt argiloso, através de um horizonte $\mathrm{A}$.

Os valores de densidade das partículas, embora aparentemente elevados nos solos derivados do Pré-Cambriano, são todos consoantes com o material de origem dos solos. 
Tabela 11 - Propriedades químicas dos perfis utilizados no experimento de campo.

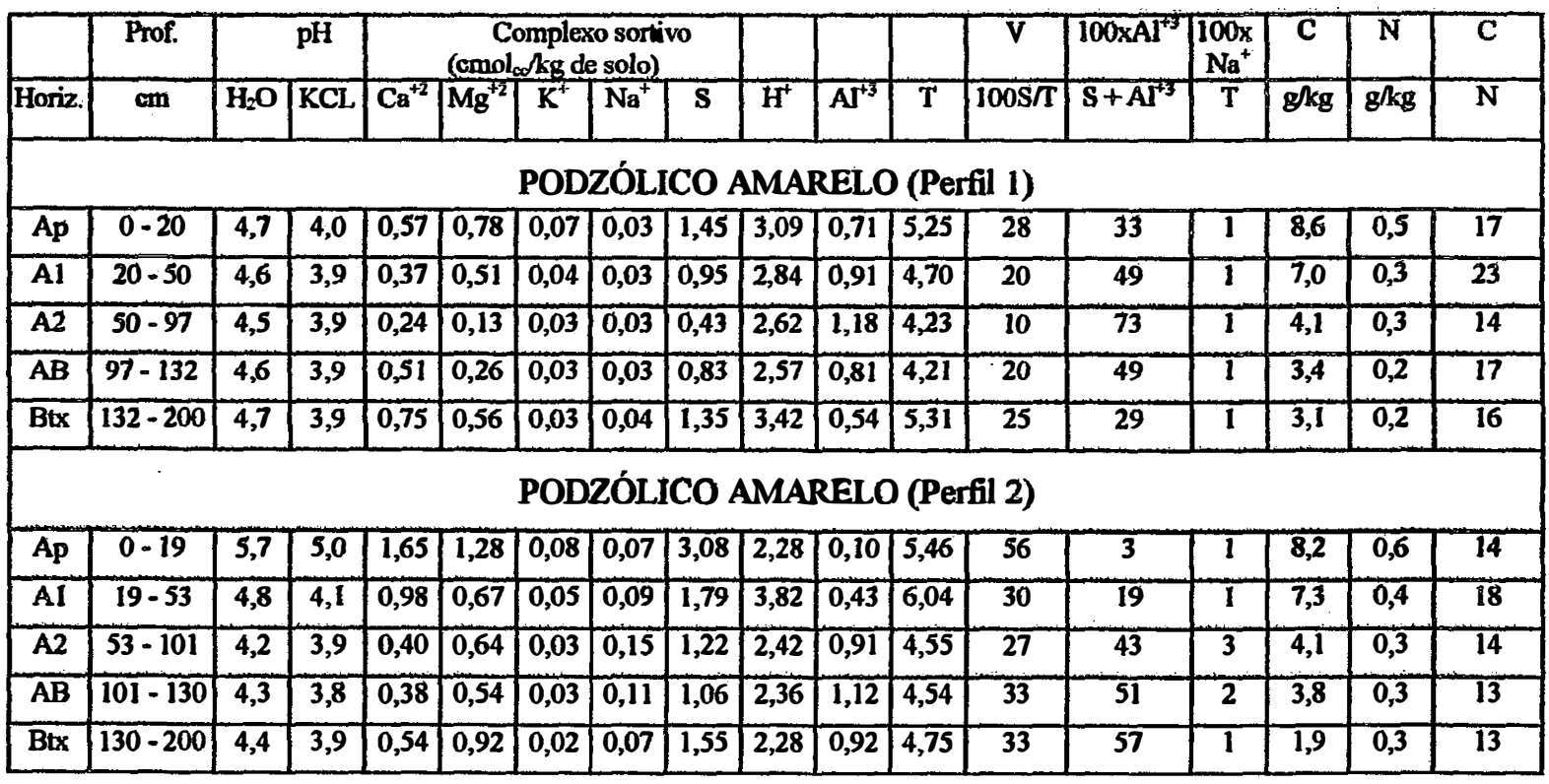

